\title{
Precipitation patterns and moisture fluxes in a sandy, tropical environment with a shallow water table
}

M. R. Minihane ${ }^{1,{ }^{\star}}$ and D. L. Freyberg ${ }^{1}$

${ }^{1}$ Department of Civil and Environmental Engineering, Stanford University, USA *now at: Department of Civil and Environmental Engineering, University of Washington, USA

Received: 5 August 2011 - Accepted: 19 August 2011 - Published: 24 August 2011

Correspondence to: M. R. Minihane (minihane@ hydro.washington.edu)

Published by Copernicus Publications on behalf of the European Geosciences Union.

Precipitation patterns and moisture fluxes in a sandy

M. R. Minihane and D. L. Freyberg

\section{Title Page}

Abstract Introduction

Conclusions References

Tables Figures

14 $\rightarrow$

4

Back

Close

Full Screen / Esc

Printer-friendly Version

Interactive Discussion 


\section{Abstract}

Identifying the dominant mechanisms controlling recharge in shallow sandy soils in tropical climates has received relatively little attention. Given the expansion of coastal fill using marine sands and the growth of coastal populations throughout the trop5 ics, there is a need to better understand the nature of water balances in these settings. We use time series of field observations at a coastal landfill in Singapore coupled with numerical modeling using the Richards' equation to examine the impact of precipitation patterns on soil moisture dynamics, including percolation past the root zone and recharge, in such an environment. A threshold in total precipitation event , much more so than peak precipitation intensity, is the strongest event control on recharge. However, shallow antecedent moisture, and therefore the timing between events along with the seasonal depth to water table, also play significant roles in determining recharge amounts. For example, at our field site, precipitation events of less than $3 \mathrm{~mm}$ per event yield little to no direct recharge, but for larger events, moisture content changes below the root zone are linearly correlated to the product of the average antecedent moisture content and the total event precipitation. Therefore, water resources planners need to consider identifying threshold precipitation volumes, along with the multiple time scales that capture variability in event antecedent conditions and storm frequency in assessing the role of recharge in coastal water balances in tropical settings.

\section{Introduction}

\subsection{Background}

While the literature describes many aspects of the spatial and temporal structure of recharge, it remains difficult to predict dominant recharge mechanisms and their con- sequences in specific settings. Previous studies have demonstrated that recharge is

8064

\section{HESSD}

8, 8063-8099, 2011

\section{Precipitation patterns and moisture fluxes in a sandy \\ M. R. Minihane and D. L. Freyberg}

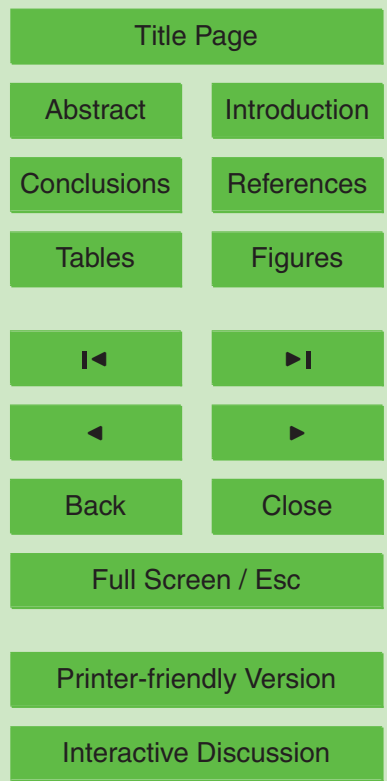


dependent on precipitation timing and intensity, antecedent moisture conditions, and depth to the water table in a variety of environments. There is insufficient evidence to describe the relative importance of these factors in a sandy, tropical setting with high precipitation and high evaporative demand.

5 It is well-documented that the critical timescale for precipitation's impact on recharge varies by location (e.g., Jones and Banner, 2003; Taylor and Howard, 1996). For example, mean annual precipitation is one of the primary factors impacting net recharge in the humid eastern United States (Nolan et al., 2007) and parts of Texas (Keese et al., 2005). In contrast, in the Victoria Nile basin in east Africa, the majority of recharge oc10 curs during heavy rainfall events (Taylor and Howard, 1996). Lewis and Walker (2002) describe conditions where infrequent and irregular precipitation is the primary source of recharge. They cite studies in southeast United States, Australia, and other locations with highly irregular precipitation or precipitation patterns with strong inter-annual variability. Jones and Banner (2003) show that seasonality in tropical climates can 15 be more important than average annual precipitation in determining annual recharge. They found higher average annual recharge when rainfall was more concentrated during the wet season rather than evenly distributed throughout the year. We present evidence supporting how both seasonality and characteristics of individual events and clusters of events can impact recharge dynamics in a sandy setting with nearly $2 \mathrm{~m} \mathrm{yr}^{-1}$ annual precipitation.

Drainage and redistribution of soil moisture after an infiltration event can determine how much moisture percolates deep enough to contribute to recharge. Broadbridge and White (1988) describe infiltration and wetting front advancement through the unsaturated zone under constant rainfall conditions. Their analytic solution shows that, in the absence of ponding, the wetting front advances faster with higher precipitation rates. Under some conditions, this could lead to a correlation between higher precipitation rates and greater recharge quantities. In our setting, however, the rain events are short and the solution provided by Broadbridge and White does not apply. Since it is not adequately described elsewhere, here we evaluate the dependence of recharge
HESSD

8, 8063-8099, 2011

\section{Precipitation patterns and moisture fluxes in a sandy}

M. R. Minihane and D. L. Freyberg

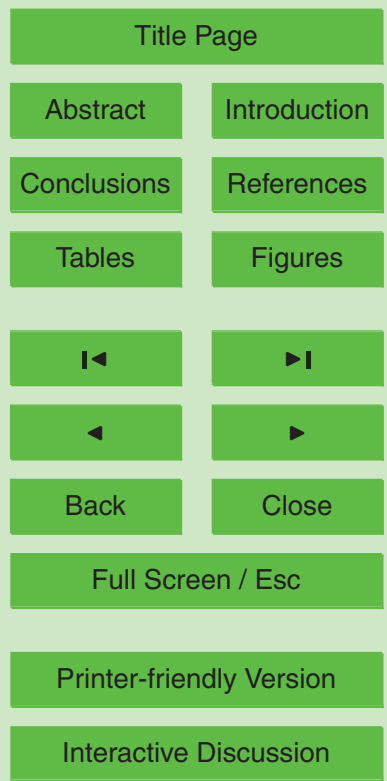


on precipitation rates versus precipitation depth.

The relative importance of gravitational versus soil matric pressure gradients for recharge determines, in part, the appropriate tools for future water resources studies in our setting. Despite some counter examples (Castillo et al., 2003), antecedent 5 moisture content typically impacts infiltration rates and shallow moisture fluxes. In unsaturated porous media, Darcy's law provides a model to link these quantities:

$q=-K(\psi)\left(\frac{d \psi}{d z}-1\right)$

where $q$ represents moisture flux per unit area $\left(\mathrm{m} \mathrm{s}^{-1}\right) ; K(\psi)$ represents unsaturated hydraulic conductivity as a function of the soil matric pressure, $\psi(\mathrm{m})$; and $z$ is the 10 vertical position in the soil profile $(m)$, positive downwards. With low soil moisture, the gravitational gradient is typically small relative to the soil matric pressure gradient, so the gravitational gradient can be neglected (Davidson et al., 1969; Sisson et al., 1980; Smith, 2002). However, with relatively wet soil, suction gradients are small and water moves primarily under the influence of gravity (Hillel, 1980). This leads to a strong between antecedent moisture content and faster percolation of moisture through the soil column. In addition, when saturated hydraulic conductivity, $K_{\mathrm{s}}$, is higher than the precipitation rate, the gravitational gradient often becomes more important than the soil matric pressure gradient (Singh, 1997; Smith, 1983).

In our sandy setting, $K_{\mathrm{s}}$ is typically higher than the precipitation rate, but the sand fluctuates between dry and wet conditions depending on seasonality and recent precipitation events. Precipitation and evaporative demand are both high and moisture has the potential to move quickly through the soil column because sand has high saturated hydraulic conductivity. These conditions are commonly found in coastal constructed fill sites, which serve as artificial land areas in regions with high population density. Such settings also often require innovative water resources planning. Water resources planners need to be able to estimate recharge to groundwater to estimate water availability if they decide to use that groundwater to supplement other fresh water sources.
HESSD

8, 8063-8099, 2011

\section{Precipitation patterns and moisture fluxes in a sandy}

M. R. Minihane and D. L. Freyberg

Title Page

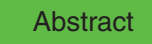

Introduction

Conclusions

References

Tables

Figures

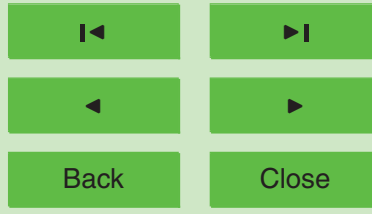

Full Screen / Esc

Printer-friendly Version

Interactive Discussion 
Here we apply both analysis of field observations and numerical modeling results to provide insight into the impact of precipitation patterns on subsurface hydrologic processes in shallow sands in humid, tropical climates. We describe the mechanisms that control how precipitation patterns impact percolation of soil moisture beyond the root 5 zone and groundwater recharge in this hydrologically dynamic environment. We use field observations supplemented by numerical modeling to describe shallow subsurface moisture fluxes in a medium sand with high precipitation and evaporative demand. Specifically, we demonstrate how recharge depends on precipitation timing, precipitation intensity, antecedent moisture conditions, and depth to water table in a sandy, 10 tropical setting with a shallow water table. Further, we discuss the relevance of these findings for future recharge and water resources studies in similar environments.

\subsection{Study site}

We observed field conditions at the Changi East Reclamation Area, a $25 \mathrm{~km}^{2}$ constructed fill site on the eastern coast of Singapore (Fig. 1). Although manmade, this 5 accessible site is a model for natural shallow sandy aquifers since the construction methods created a stratigraphy that is consistent with natural aquifers (Chua et al., 2007). The Changi East Reclamation Area was constructed using dredged marine sands placed using dynamic compaction and surcharge, with vertical drains to facilitate compaction by releasing moisture from the underlying clays (Choa, 1995). Three sides of this area are coastal, bordering the Singapore Straight, and the fourth side is adjacent to an older fill, which now hosts the Changi International Airport. The coastal edges of the fill are protected by geotechnical erosion control structures. The land surface is relatively flat with sparse vegetation. Two main horizontal surface drainage channels enhance drainage after rainfall events and establish a base water table eledirectly to the Singapore Strait. This study is one of several carried out at this site exploring the feasibility of using the area for groundwater storage and in situ treatment (Chua et al., 2007; Ngonidzashe, 2004; Tan et al., 2007c).

\section{HESSD}

8, 8063-8099, 2011

\section{Precipitation patterns and moisture fluxes in a sandy \\ M. R. Minihane and D. L. Freyberg}

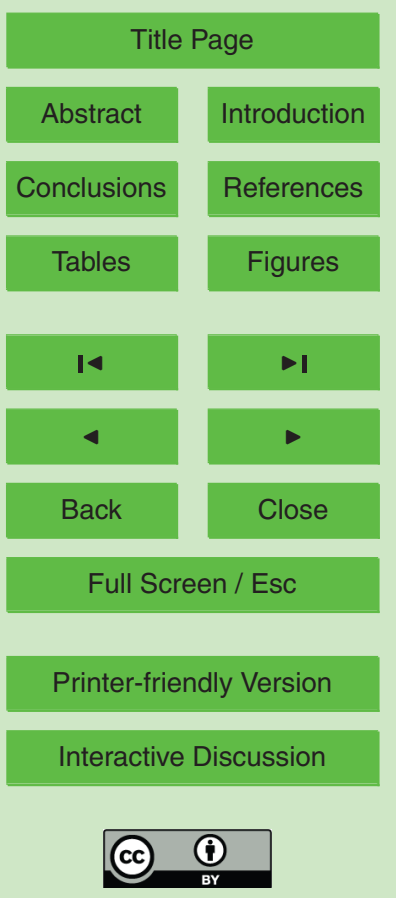




\subsubsection{Hydrogeology}

The constructed fill material is primarily medium sand, with less than $10 \%$ shells and less than $1 \%$ silt content (Chua et al., 2007). The average particle size is $0.42 \mathrm{~mm}$. The porosity of the sand ranges from 0.31 to 0.40 over the area (Chua et al., 2007; 5 Ngonidzashe, 2004). A sample taken from the top $0.50 \mathrm{~m}$ of sand at the field site has an estimated porosity of 0.36 (Minihane, 2008). The estimated horizontal saturated hydraulic conductivity $\left(K_{\mathrm{s}}\right)$ ranges between $13 \mathrm{~m} \mathrm{~d}^{-1}$ and $220 \mathrm{~m} \mathrm{~d}^{-1}$ (Chua et al., 2007; Ngonidzashe, 2004; Tan et al., 2004). Chua et al. (2007) estimate a vertical $K_{\mathrm{s}}$ of $6 \mathrm{~m} \mathrm{~d}^{-1}$ based on a point measurement. This suggests an anisotropy ratio between 2:1

10 and $36: 1$, with a higher hydraulic conductivity in the horizontal direction, as expected for a constructed fill placed in horizontal lifts and consistent with typical natural aquifers.

The field site is located within $1 \mathrm{~km}$ of the coast, however, water table observations at the site show no diurnal fluctuations consistent with tidal influence (Minihane, 2008). Ngonidzashe et al. (2004) provide a theoretical analysis explaining this observation. 15 They estimate that the tidal influence on water table fluctuations extends less than $300 \mathrm{~m}$ to $500 \mathrm{~m}$ from the coast; the field site itself is further inland. Therefore, tidal fluctuations do not significantly impact infiltration and percolation in this setting.

While the provenance of the site is anthropogenic, Chua et al. (2007) demonstrated that the hydraulic conductivity of the fill material is similar to naturally-derived soils with similar texture. Therefore, our results are relevant for both constructed fill sites as well as natural areas with similar characteristics.

\subsubsection{Climate}

Singapore's climate is humid and tropical with precipitation occurring throughout the year. The weather is characterized by relatively uniform temperature and an average relative humidity of $84 \%$, varying between $41 \%$ and $100 \%$. The diurnal temperature typically ranges from a daily minimum of $23^{\circ} \mathrm{C}$ to $26^{\circ} \mathrm{C}$ to a daily maximum of $30^{\circ} \mathrm{C}$ to $32^{\circ} \mathrm{C}$ (Singapore National Environment Agency, 2010). Air temperatures recorded at

\section{HESSD}

8, 8063-8099, 2011

\section{Precipitation patterns and moisture fluxes in a sandy \\ M. R. Minihane and D. L. Freyberg}

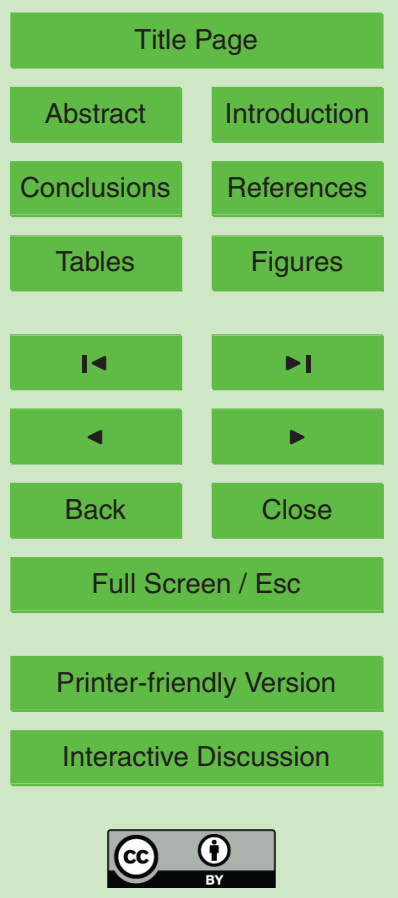


the field site are frequently higher than the values published by the Singapore National Environment Agency for the nearby Changi International Airport, with the daily high often reaching $40^{\circ} \mathrm{C}$. A brief description of local climate can be found on the Singapore National Environment Agency website (2010) or in Gupta et al. (1992).

5 Ten years of daily precipitation and pan evaporation data at the Changi International Airport meteorological station (Fig. 2; data purchased from the Singapore National Environment Agency in 2004) provides a sense of seasonality in this region. Precipitation is distributed throughout the year with a modest seasonal pattern because of regional monsoonal weather. Rainfall is generally higher during the northeast monsoon 10 (December-March) and lower during the southwest monsoon (June-September). The daily precipitation record from the ten-year period (1994-2003) shows that rain was recorded on 1760 days out of 3652 days: nearly half of the days. The maximum recorded precipitation in a single day was $211.1 \mathrm{~mm} \mathrm{~d}^{-1}$, but most days had $10 \mathrm{~mm} \mathrm{~d}^{-1}$ or less rainfall. The recorded average annual precipitation is about $1.90 \mathrm{~m} \mathrm{yr}^{-1}$. While the field site is within $15 \mathrm{~km}$ of the Changi Airport meteorological station, weather patterns at the field site are generally slightly drier.

Over the period from 1994 to 2003, daily pan evaporation at the Changi International Airport meteorological station ranged from $0.3 \mathrm{~mm} \mathrm{~d}^{-1}$ to $9.5 \mathrm{~mm} \mathrm{~d}^{-1}$, with a mean value of $5 \mathrm{~mm} \mathrm{~d}^{-1}$. In contrast to rainfall, evaporation decreases in response to the increased moisture levels during the northeast monsoon. For most months, precipitation exceeds pan evaporation, particularly from October through January. However, $10-y r$ average monthly pan evaporation exceeded precipitation for March, June, July, and September.

\subsubsection{Recharge}

25 The seasonal differences between precipitation and evaporative demand result in greater recharge during the northeast monsoon (December-March). This corresponds to the seasonally fluctuating water table at the field site which is typically shallower December-March than it is the rest of the year.

\section{HESSD}

8, 8063-8099, 2011

\section{Precipitation patterns and moisture fluxes in a sandy \\ M. R. Minihane and D. L. Freyberg}

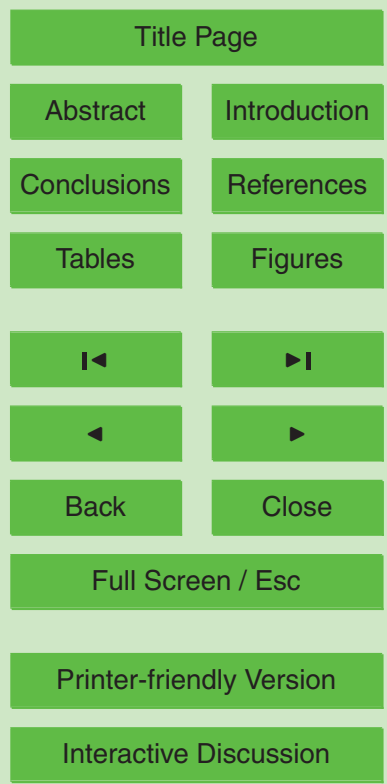


In a series of studies based on conditions at the Changi East Reclamation Area in Singapore, Tan and colleagues investigated the impact of hydrogeological and meteorological factors on recharge characteristics (Tan et al., 2007a, b, c). Their results show that the fraction of precipitation that becomes recharge depends on rainfall patterns and 5 water table depth (Tan et al., 2007a; Tan et al., 2007c) and suggest that rainfall intensity has the most significant impact on recharge quantities (Tan et al., 2007a). We add to their results by providing details on the mechanisms relating recharge and precipitation patterns.

\section{Methods}

10 This study combines monitoring of subsurface conditions at a well-characterized field site with more generalized numerical modeling experiments. Direct field observations reveal the time-varying soil moisture conditions at three depths in the subsurface. However, these field observations alone are insufficient to evaluate how precipitation characteristics and soil conditions together influence percolation and redistribution pro-

15 cesses at this site. Numerical modeling allows us to extend knowledge gained from the field data to a broader range of soil and meteorologic conditions.

\subsection{Field data collection}

The goals of the field campaign were to observe and characterize the moisture fluxes through the unsaturated zone from the ground surface to a depth below the root zone.

20 The wetting front advancement is assessed via relatively high-frequency moisture content measurements at three depths for a 9-month period in 2005. Precipitation and other hydrometeorological parameters were also measured at the site to evaluate how they influence wetting front advancement.

Soil moisture was measured on 10-min intervals using time domain reflectome25 try (TDR) with $0.30 \mathrm{~m}$ long 3-rod probes (Models TDR100 (reflectometer), SDMX50

\section{HESSD}

8, 8063-8099, 2011

\section{Precipitation patterns and moisture fluxes in a sandy \\ M. R. Minihane and D. L. Freyberg}

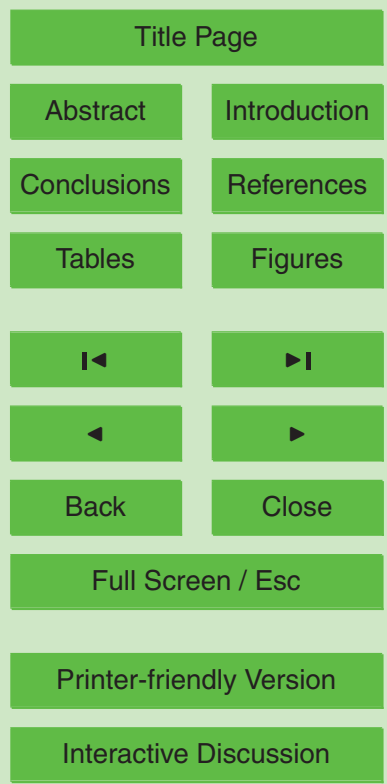


(multiplexer), and CS605 (probes); Campbell Scientific, Logan, UT). A total of three probes were installed horizontally, as follows: a piece of plywood, $0.5 \mathrm{~m}$ wide and $0.7 \mathrm{~m}$ tall, with pre-drilled holes for each of the soil moisture instruments was installed vertically with the sand excavated on one side to enable access. One soil moisture 5 probe was installed at each of three depths: $0.10 \mathrm{~m}, 0.35 \mathrm{~m}$, and $0.50 \mathrm{~m}$. The probes were staggered horizontally to reduce impacts of soil disturbance during placement. The open pit created for equipment installation on one side of the plywood was backfilled with native materials after all instruments were in place. The TDR readings were converted to moisture contents using parameters appropriate to the CS605 probes, as specified in the instruction manual (Campbell Scientific, 2009).

Hydrometeorological parameters at the field site were recorded for several periods that overlap the soil moisture observations (Ngonidzashe, personal communication, 2005). Precipitation data were collected using a tipping bucket rain gauge for several periods from 2003 to 2005. Surface air temperature, full spectrum solar radiation $\left(R_{\mathrm{s}}\right)$, relative humidity, and wind speed recorded at the field site on 15-min intervals supplement the daily pan evaporation data from the Changi International Airport. We use a Penman-Monteith combination equation (California Irrigation Management Information System, 2010; Allen et al., 1998, 2005) to estimate hourly reference crop evapotranspiration.

\subsection{Numerical model}

A one-dimensional finite element model approximating solutions to Richards' equation (COMSOL AB, version 3.4) describes moisture fluxes in a soil column. Established theoretical work suggests that variably-saturated flow through homogeneous soil is predominantly vertical (Bartolino and Niswonger, 1999; Freeze, 1969). We assume a homogeneous soil profile with vertical moisture flow. This is consistent with a study of the site hydrostratigraphy (Chua et al., 2007) that described a largely homogeneous vadose zone.

\section{HESSD}

8, 8063-8099, 2011

\section{Precipitation patterns and moisture fluxes in a sandy \\ M. R. Minihane and D. L. Freyberg}

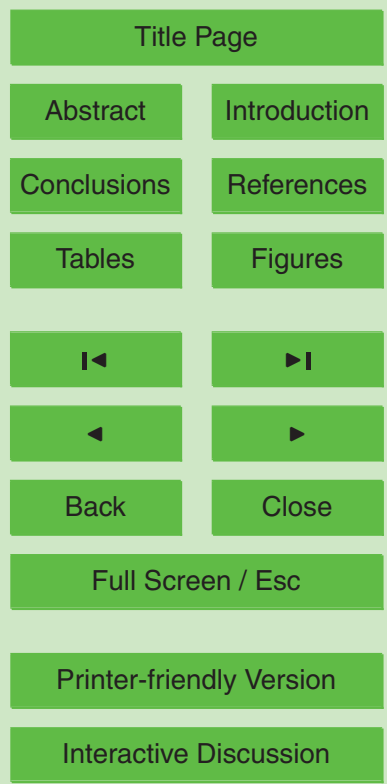


A balance of computation requirements and mass balance and flux accuracies determines spatial and temporal discretizations. A mesh size of $0.001 \mathrm{~m}$ is used over the middle of the domain and then decreases smoothly to $0.0001 \mathrm{~m}$ within $0.15 \mathrm{~m}$ of the top and bottom boundaries. This spatial discretization reduces mass balance errors to 5 less than $0.1 \%$ of the initial stored soil moisture. The maximum time step is $60 \mathrm{~s}$, which is necessary for accurate flux calculations. The initial model state is specified as static hydraulic head conditions without evaporative demand.

For each simulation, the water table is fixed at the bottom of the computational domain. To explore the effects of the depth of the water table over ranges observed at 10 the field site, we adjust this fixed water table depth to $1 \mathrm{~m}, 2 \mathrm{~m}$, and $3 \mathrm{~m}$. The upper boundary condition is a specified flux equal to the precipitation rate. The observed precipitation rate is always less than the estimated $K_{\mathrm{s}}$, so surface saturation and ponding do not occur, as discussed in the results section.

The bare soil evaporative demand in these simulations is extracted uniformly from 15 the top $0.05 \mathrm{~m}$ of soil. The estimated evaporative demand (units of $\mathrm{m} \mathrm{s}^{-1}$ ) is divided by the length of the extraction zone to determine the sink intensity used as the model input in units of inverse seconds. Modeled actual evaporation is calculated based on a combination of demand and soil moisture availability. Evaporation is assumed to be negligible during precipitation events.

20 The soil and meteorological parameters are derived from field measurements and laboratory observations. Site data are used to inform the selection of model parameters and meteorological inputs rather than to calibrate and validate the model. Most of the numerical modeling experiments use one set of soil parameter values; however, a sensitivity analysis is used to evaluate the relative soil moisture response for a range 25 parameter values. The baseline $K_{\mathrm{s}}$ used in the simulations is $8 \mathrm{~m} \mathrm{~d}^{-1}$ based on previous work at the field site (Chua et al., 2007; Ngonidzashe, 2004; Tan et al., 2004) and we run simulations using a modest range bracketing that value $\left(80 \mathrm{~m} \mathrm{~d}^{-1}-0.8 \mathrm{~m} \mathrm{~d}^{-1}\right.$; Table 1). The porosity is taken as 0.36 based on a point estimate at the field site that is consistent with the range measured previously across the reclamation area. The

\section{HESSD}

8, 8063-8099, 2011

\section{Precipitation patterns and moisture fluxes in a sandy}

M. R. Minihane and D. L. Freyberg

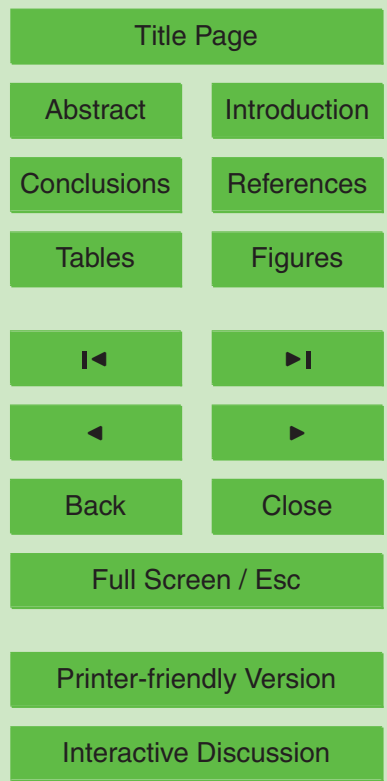


van Genuchten moisture retention and relative permeability curves (van Genuchten, 1980) are used to model these variably-saturated soil properties. Pressure plate observations in the laboratory using a sample from the field site inform the selection of moisture retention characteristic curve parameters (Minihane, 2008). Table 1 provides 5 a summary of the parameter values used for the analysis.

\section{Field results}

\subsection{Observed precipitation rates}

Most of the observed 15-min rainfall intensities at the field site (September 2003 through January 2004) are less than $10 \mathrm{~mm} \mathrm{~h}^{-1}$. For this period, the highest recorded 1015 -min intensity is equal to $105 \mathrm{~mm} \mathrm{~h}^{-1}$. The estimated vertical $K_{\mathrm{s}}$ at the field site $\left(6 \mathrm{~m} \mathrm{~d}^{-1}\right.$ or $250 \mathrm{~mm} \mathrm{~h}^{-1}$; Chua et al., 2007) is higher than any of the 15-min rainfall intensities recorded in this time period or those reported by Fook (1992). Based on this comparison, and supported by observations at the field site, ponding does not typically occur and infiltration excess (Hortonian) overland flow generation is rare here.

\subsection{Moisture content response to precipitation patterns}

Field observations of moisture content during percolation of individual precipitation events demonstrate key aspects of the relationship between precipitation characteristics and percolation through the shallow vadose zone in this environment. We compare the precipitation events and subsequent soil moisture changes to provide insight into the relative impact of precipitation depth, precipitation intensity, and antecedent moisture content on recharge in this sandy, tropical environment.

Soil moisture and precipitation recorded at three depths during a sample 25-day period demonstrate soil moisture conditions in the absence of precipitation and in response to precipitation events (Fig. 3). Moisture content generally increases with
HESSD

8, 8063-8099, 2011

Precipitation patterns and moisture fluxes in a sandy

M. R. Minihane and D. L. Freyberg

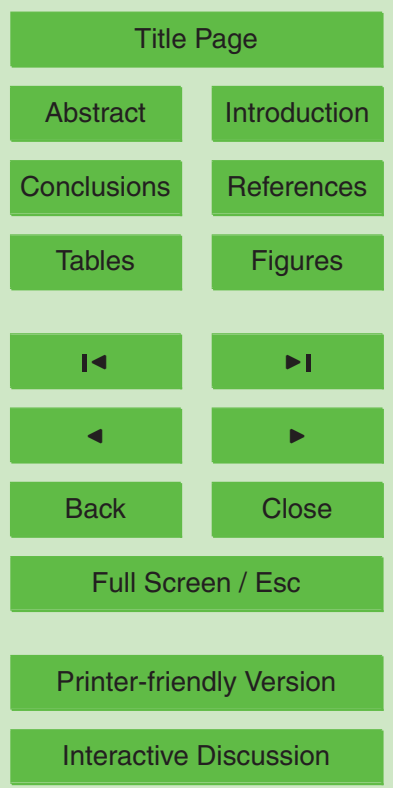


depth, and moisture content changes are typically observed at all three depths in response to larger precipitation events. However, there are some events for which a moisture content change is only observed in the shallowest location. In this short sample period, three distinct soil moisture responses are observed. On Day of Year (DOY)

5 86-87, the shallowest soil moisture increases quickly in response to precipitation; after the shallow moisture content peaks and begins to decrease, the deeper moisture contents gradually increase, suggesting relatively slow propagation of a wetting front down through the first $0.50 \mathrm{~m}$ of the soil column. The soil moisture does not return to antecedent moisture content levels following the event. In contrast, on DOY 92, moisture 10 content increases at the shallowest measurement point in response to precipitation on that day, but not at the deeper measurement points. Finally, on DOY 94-95, the soil moisture responds rapidly at all three depths in the soil column. For this event, the soil moisture profile less than one day after the precipitation event begins is close to the initial moisture profile.

15 Figure $4 a, b$, and c zooms in on three days from another time period to compare the 24-h dynamics associated with infiltration and percolation events. These events were chosen because they have similar total event depth: $7.4 \mathrm{~mm}, 7.1 \mathrm{~mm}$, and $8.1 \mathrm{~mm}$, but different maximum 15-min precipitation intensities.

On DOY 132, the maximum 15-min precipitation intensity is $4 \mathrm{~mm} \mathrm{~h}^{-1}$ and the initial 20 soil moisture is $0.09,0.13$, and 0.17 at $0.10 \mathrm{~m}, 0.35 \mathrm{~m}$, and $0.50 \mathrm{~m}$, respectively. Propagation of the wetting front through the soil is gradual, as is the falling moisture content during drainage. In comparison, the maximum precipitation intensity for an event on DOY 145 is greater $\left(12 \mathrm{~mm} \mathrm{~h}^{-1}\right)$, and the initial soil moisture before the wetting front arrival at each depth is higher $(0.13,0.19$, and 0.20 , respectively). The sharp wetting front propagates much faster through the shallow soil for this event. The third event (DOY 183) has a total of $8.1 \mathrm{~mm}$ of precipitation, largely occurring in a single 15-min period. The initial moisture content is similar to that on DOY 132, but the precipitation intensity is much higher, approximately $30 \mathrm{~mm} \mathrm{~h}^{-1}$. The shallow moisture response is fast, but the wetting front does not propagate quickly beyond $0.10 \mathrm{~m}$. The deeper soil
HESSD

8, 8063-8099, 2011

\section{Precipitation patterns and moisture fluxes in a sandy}

M. R. Minihane and D. L. Freyberg

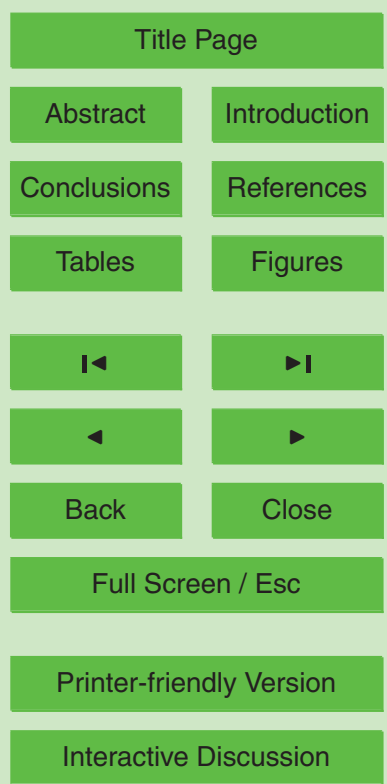


moisture response is similar to that of the longer, less intense event on DOY 132.

Of these three events, the only one for which the wetting front propagates quickly beyond the top $0.10 \mathrm{~m}$ is the event on DOY 145 , which has the highest initial moisture content. This event has neither the highest maximum precipitation rate nor the greatest 5 precipitation depth.

\subsection{Moisture content change at $0.5 \mathrm{~m}$}

We have chosen to use moisture content change at $0.50 \mathrm{~m}$ as a metric for estimating relative event contribution to recharge. Of the 34 events recorded at the field site, 24 resulted in a moisture content change at $0.10 \mathrm{~m}$, but only 16 resulted in a measurable 10 moisture content change at $0.50 \mathrm{~m}$. In Fig. 5, the moisture content change at $0.50 \mathrm{~m}$ is compared to both the maximum 15-min precipitation rate (upper plot) and the total precipitation depth (lower plot) for each event. The moisture content change is determined by taking the difference between the moisture content at the start of the infiltration event and the maximum moisture content at the same depth following the infiltration event.

15 There is a significantly stronger linear relationship with the rainfall quantity than with the maximum 15-min precipitation rate.

A different view of the data provides insight into the relative impact of precipitation event depth and antecedent moisture content. Figure 6 presents two scatter plots, both showing the maximum change in moisture content at $0.50 \mathrm{~m}$ for each event as 20 a function of the change in moisture at $0.10 \mathrm{~m}$. In Fig. 6a, black diamonds indicate the events with precipitation depths less than $3 \mathrm{~mm}$ and grey squares indicate larger events. Most of the events with smaller depths do not result in soil moisture change at $0.50 \mathrm{~m}$. Events with depths greater than $3 \mathrm{~mm}$ produce observed moisture responses at $0.10 \mathrm{~m}$ and $0.50 \mathrm{~m}$, with a stronger response at $0.10 \mathrm{~m}$.

25 Figure $6 \mathrm{~b}$ distinguishes the events with average initial moisture content (calculated from the three observation points) above 0.13 (black diamonds) from those with lower initial moisture content (grey squares). For wetter initial conditions, a given change in moisture content at $0.10 \mathrm{~m}$ corresponds to a greater change in moisture content at
HESSD

8, 8063-8099, 2011

Precipitation patterns and moisture fluxes in a sandy

M. R. Minihane and D. L. Freyberg

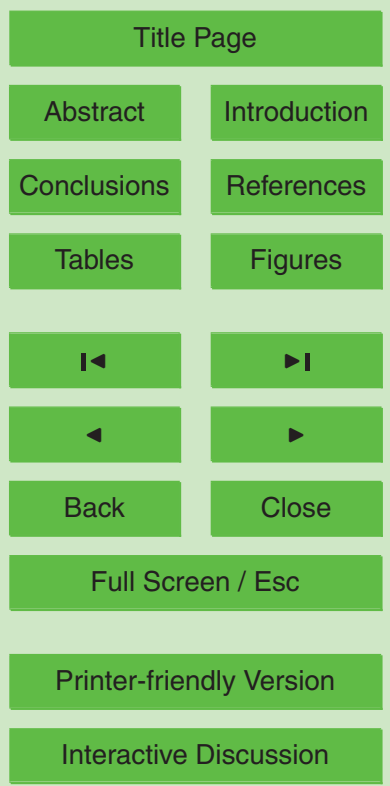


$0.50 \mathrm{~m}$. This confirms that higher antecedent moisture content promotes propagation of moisture through the soil column as is consistent with gravity-dominated drainage typical in wet climates.

The product of the antecedent moisture content and the precipitation depth is pro5 posed as a way to predict the moisture content change at depth for a specific precipitation event. Figure 7 shows that the change in soil moisture at $0.50 \mathrm{~m}$ following each precipitation event is strongly correlated with the product of the antecedent moisture content and the precipitation depth. The coefficient of determination, $R^{2}$, for the best-fit line is 0.98 . This therefore suggests that a combination of antecedent moisture content 10 and precipitation depth is likely to be the best indicator for recharge in response to individual events. The sequential and seasonal timing of precipitation events impacts the antecedent moisture content since the moisture is higher following previous events and when the water table is close to the ground surface. Therefore, both daily and seasonal precipitation characteristics are relevant to recharge studies.

\section{Modeling results}

We use the one-dimensional numerical model to supplement the field data and to extend the insight gained from the field observations to a broader range of meteorological conditions. The numerical modeling results demonstrate the relative impacts of precipitation patterns on subsurface moisture fluxes and recharge under a modest range of

\subsection{Qualitative comparison with field observations}

The intent of comparing field and modeling results is neither to calibrate the numerical model nor to exactly replicate a specific event in the field. Rather the purpose is to demonstrate that the dominant hydrologic processes represented in the model are
HESSD

8, 8063-8099, 2011

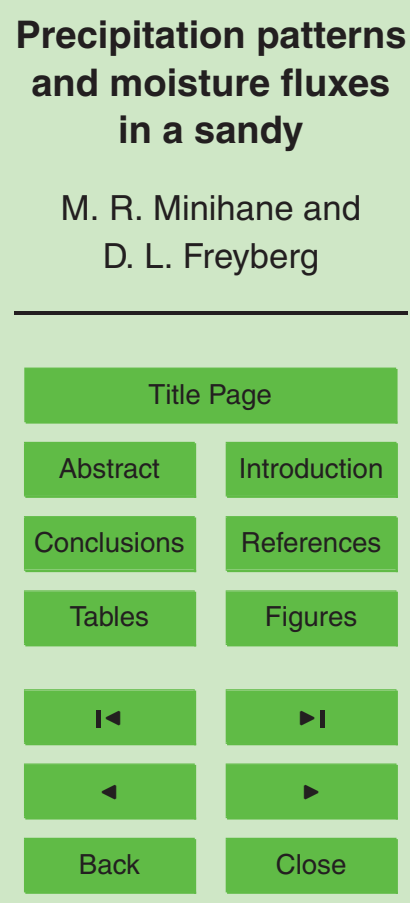

Full Screen / Esc

Printer-friendly Version

Interactive Discussion 
Recorded precipitation and estimated evaporative demand from 24 March to 2 April (DOY 83-92) are used as a baseline for model inputs (Fig. 8, simulation days 1-10). This period is used because the events on days 4 and 6 are isolated from other events, making it relatively straightforward to distinguish the shallow subsurface response to 5 these events from the responses to other events. Since this exercise is designed to explore relative trends rather than to calibrate the model to field data, the initial soil moisture profile of the model is not fit to field data, but rather a static equilibrium condition is used. This is likely a reasonable condition when there is about one week or more between events.

10 Figure 9 compares panel (a) the time series of the moisture content field measurements from 24 March to 2 April (DOY 83-92) at three depths $(0.10 \mathrm{~m}, 0.35 \mathrm{~m}$, and $0.50 \mathrm{~m}$ ) with panels $(\mathrm{b}-\mathrm{c})$ the simulated moisture content at the same depths when the water table is $1 \mathrm{~m}$ and $2 \mathrm{~m}$ deep and $K_{\mathrm{s}}$ equals $8 \mathrm{~m} \mathrm{~d}^{-1}$. With the simulated water table at $2 \mathrm{~m}$, the initial moisture contents of the model are drier than the field observations. 15 However, when the water table is at $1 \mathrm{~m}$, the model initial conditions are wetter than the observations. This provides a range of results for our qualitative comparison. For both field observations and modeling results, the shallow moisture content responds quickly to infiltration events, while the deeper moisture contents respond more gradually. When the water table is at $1 \mathrm{~m}$, the infiltration front moves more quickly through the top $0.5 \mathrm{~m}$ compared to the $2 \mathrm{~m}$ simulation. The field observations show more rapid drainage after passage of the wetting front with a similarly more rapid and distinctive response at depth. The diurnal evaporation signal is evident in both the field observations (e.g., DOY 84-86) and the modeling results (e.g., days 2 and 3).

The simulated moisture content response when the water table is $2 \mathrm{~m}$ deep and $K_{\mathrm{s}}$ 25 is (a) $80 \mathrm{~m} \mathrm{~d}^{-1}$ and (b) $0.8 \mathrm{~m} \mathrm{~d}^{-1}$ provides additional insight into this system (Fig. 10). Both simulations start with the same moisture distribution above the water table, but the higher $K_{\mathrm{s}}$ leads to more evaporation and therefore lower moisture contents at the beginning of the precipitation event on day 4 . In response to the event on day 4 , the shallow moisture content peaks lower and drains faster when $K_{\mathrm{s}}$ is higher. The rapid

\section{HESSD}

8, 8063-8099, 2011

\section{Precipitation patterns and moisture fluxes in a sandy}

M. R. Minihane and D. L. Freyberg

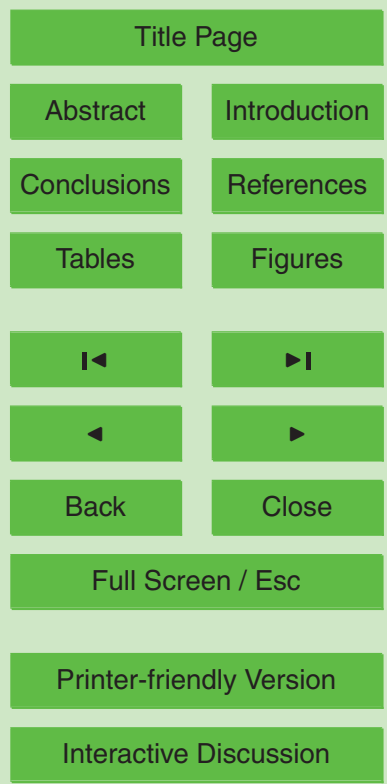


drainage in the high $K_{\mathrm{s}}$ case causes the deeper moisture contents to respond; there is no visible response in deeper moisture content for the low $K_{\mathrm{s}}$ case. The smaller infiltration events after day 4 do not cause a noticeable moisture content change at any depth when $K_{\mathrm{s}}$ is low, indicating that little of the infiltrating moisture reaches $0.1 \mathrm{~m}$. Moisture 5 from these events contributes directly to evaporation and to fill the soil moisture deficit caused by previous evaporation near the top of the domain.

\subsection{Precipitation depth and intensity}

It is informative to explore the trade-offs between precipitation depth and precipitation intensity in controlling soil moisture response. This series of simulations uses the do10 main, initial conditions and evaporative demand of the previous set of simulations with a fixed water table at $2 \mathrm{~m}$. Figure 11 compares the simulated moisture content for the three depths: $0.10 \mathrm{~m}, 0.35 \mathrm{~m}$, and $0.50 \mathrm{~m}$. Each plot presents 10 -day simulation results for either the observed (Fig. 11a) or a modified version (Fig. 11b-c) of the precipitation pattern in Fig. 8a. In all three cases the model-calculated actual evaporation is 5 soil-moisture-limited.

Figure 11a shows the simulated moisture content response to the precipitation sequence shown in Fig. 8. The initial moisture content in the top $0.50 \mathrm{~m}$ is between 0.075 and 0.085 , increasing with depth. The moisture content at $0.10 \mathrm{~m}$ is constant for the first $1 / 3$ day, and then decreases gradually until the precipitation event on day 4 . In response to the first two events (simulation days 4 and 6), the shallow moisture content increases quickly and the moisture contents at $0.35 \mathrm{~m}$ and $0.50 \mathrm{~m}$ increase slowly. At $0.10 \mathrm{~m}$, the moisture content peaks just above 0.13 , and then drops quickly at a decreasing rate, showing small effects of the diurnal evaporation signal. The arrival of the wetting front at $0.35 \mathrm{~m}$ from the first event is clear, but the arrival of the second event is

\section{HESSD}

8, 8063-8099, 2011

\section{Precipitation patterns and moisture fluxes in a sandy \\ M. R. Minihane and D. L. Freyberg}

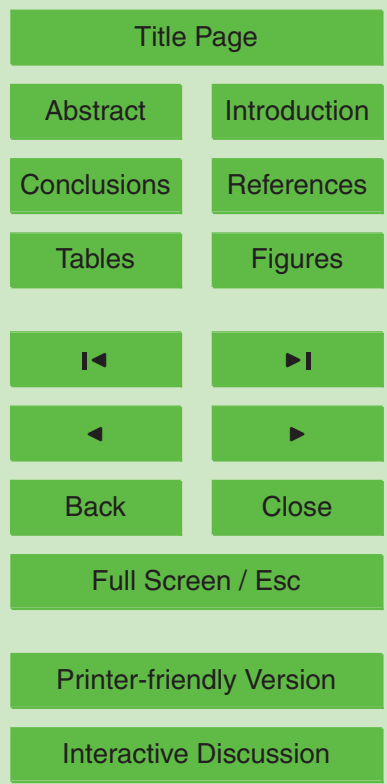


Figure $11 \mathrm{~b}$ shows the simulated response to the rainfall time series of Fig. 8 a scaled by a factor of 0.5 (half the precipitation rate and therefore with half the total volume). The peak moisture content at $0.10 \mathrm{~m}$ is lower and less sharp than in the other two cases. The moisture content at $0.10 \mathrm{~m}$ falls more slowly, and the moisture contents 5 at $0.35 \mathrm{~m}$ and $0.50 \mathrm{~m}$ increase more gradually, demonstrating slower drainage than for the previous example. In addition, the moisture content at $0.10 \mathrm{~m}$ and lower does not respond to the second precipitation event (day 6$)$. Since this is a small event $(<3 \mathrm{~mm}$ per event), it contributes solely to meeting evaporative demand, or the moisture deficit created by evaporative demand.

10 For Fig. 11c, the precipitation intensities of Fig. 8 a are scaled by 0.5 , but each $15-$ min precipitation block is extended to a 30-min block. Since events are twice as long but each event starts at the same time as the original time series, time lapse between events is slightly shorter. The shapes of the moisture content time series are very similar to those in Fig. 11a, which suggests that precipitation intensity has less of an impact on subsurface moisture conditions than total precipitation depth for these conditions.

\subsubsection{Antecedent moisture content}

We used the one-dimensional model with the observed 10-day meteorological forcings (Fig. 8) to evaluate the impact of antecedent moisture content on wetting front advancement. The initial moisture content profile is equal to static equilibrium with the water table at $2 \mathrm{~m}$. The shallow antecedent moisture content for the event on day 4 is raised using two different approaches: 1) raising the water table from $2 \mathrm{~m}$ to $1 \mathrm{~m}$, and 2) prescribing a steady influx of $8.6 \mathrm{~mm} \mathrm{~d}^{-1}$ at the ground surface for the first three days of the simulation (with the water table at $2 \mathrm{~m}$ ). This influx then stops at the end of the third day so the wetting front for the first three days of rain can be readily distinguished from the wetting front resulting from the precipitation on day 4.

Figure 12 compares the moisture content at three depths for each of these simulations. For the scenarios without precipitation in the first three days ( $a$ and $b$ ), the shallow soil moisture gradually decreases from the initial condition in response to

\section{HESSD}

8, 8063-8099, 2011

\section{Precipitation patterns and moisture fluxes in a sandy \\ M. R. Minihane and D. L. Freyberg}

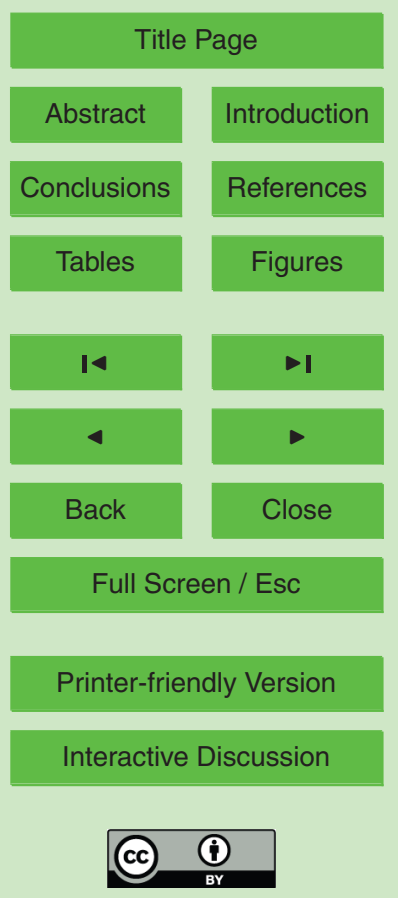


evaporative demand. When there is precipitation during the first three days, Fig. 12c, the moisture content increases, and therefore the fluctuations due to diurnal evaporative demand are much more evident in the shallow soil. For all three simulations, the shallow moisture content increases quickly in response to the rain event on day 4 . The 5 shallow drainage and subsequent increase in moisture content deeper in the soil profile happens more quickly when the moisture content at the start of the event on the fourth day is higher. While the peak moisture content at $0.10 \mathrm{~m}$ varies with each scenario, the change in moisture content at $0.10 \mathrm{~m}$ is approximately 0.06 in all three cases, though slightly higher for the driest case. The deeper moisture contents increase faster with 10 higher initial moisture contents. This is a consequence of faster percolation of infiltrating moisture and is consistent with gravity-dominated soil moisture fluxes.

\section{Discussion and conclusions}

Our field observations and modeling results demonstrate the relative influences of precipitation depth, intensity and timing on percolation of soil moisture and groundwater recharge. The numerical model provides additional insight into hydrologic processes that determine the impact of precipitation patterns on recharge for a modest range of conditions. The numerical results are consistent with our field observations and are relevant to both constructed fill areas and naturally-derived shallow sandy aquifers in tropical climates.

\subsection{Precipitation depth and intensity}

Both our field observations and modeling results show that in this setting wetting front advancement beyond the root zone has a stronger correlation to precipitation depth than to 15-min precipitation intensity. This contrasts with work by Broadbridge and White (1988) who suggest the opposite. The explanation for this difference lies in the

\section{HESSD}

8, 8063-8099, 2011

\section{Precipitation patterns and moisture fluxes in a sandy \\ M. R. Minihane and D. L. Freyberg}

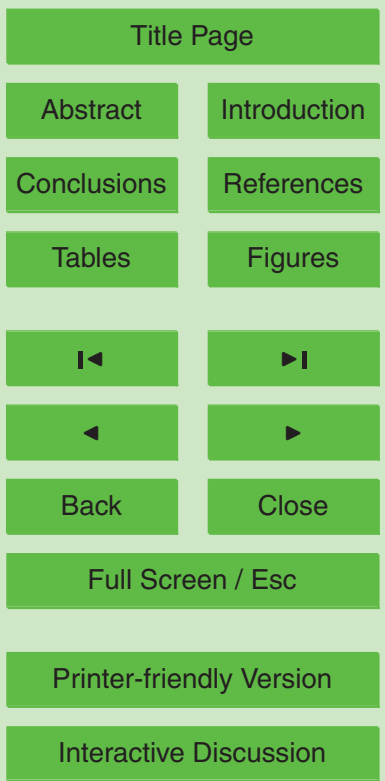


sustained events considered in previous studies. Our results also build on work by Tan et al. (2007a), who evaluated recharge from 24-h events, but whose experimental design did not distinguish between the impacts of intensity versus depth. Here we have isolated the impact of intensity from depth and demonstrated that due to the relatively 5 short duration of events in this region and the high $K_{\mathrm{s}}$, recharge quantity depends more on the precipitation depth of each event than on precipitation intensity during events.

\subsection{Precipitation depth and evaporative demand}

While we found that larger events are more likely to contribute to recharge, recharge is not a linear function of precipitation depth. Most precipitation events less than $3 \mathrm{~mm}$ 10 per event do not show measureable change in moisture content beyond $0.1 \mathrm{~m}$ below the ground surface. For comparison, daily evaporative demand during this time period averages about $4 \mathrm{~mm} \mathrm{~d}^{-1}$. Following small events, the infiltrating moisture remains in the shallow soil either to replenish a soil moisture deficit caused by evaporation, or the moisture contributes directly to evaporation before it has sufficient time to drain to $0.50 \mathrm{~m}$. Infiltration from these events is unlikely to contribute to recharge. This is consistent with previous field studies (Sophocleous and Perry, 1985) in which infiltrating moisture tends to fill the moisture deficit created by extended dry periods and evaporation.

\subsection{Antecedent soil moisture}

20 Both field observations and modeling results confirm the conclusions of others that higher antecedent moisture conditions facilitate the propagation of the wetting front through the vadose zone. Focusing on those precipitation events that propagate below $0.1 \mathrm{~m}$ below ground surface, higher antecedent moisture conditions result in deeper percolation and greater recharge potential. This behavior implies gravity-driven flows.

25 Antecedent moisture content in the shallow subsurface is higher when either the water table is shallower or within $24 \mathrm{~h}$ after a precipitation event. Higher antecedent moisture
HESSD

8, 8063-8099, 2011

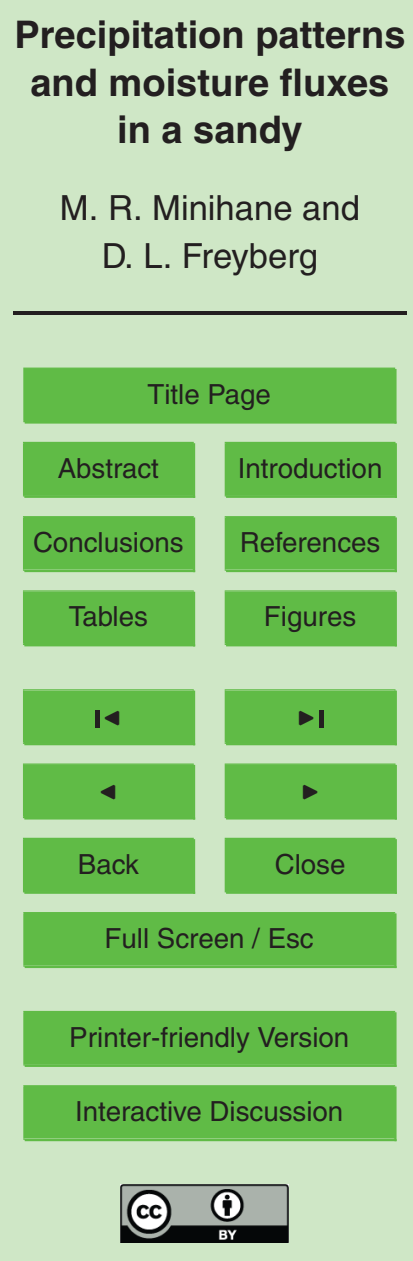


content in the shallow subsurface at the field site is associated with either a shallow water table or with a recent $(<24 \mathrm{~h})$ precipitation event. Therefore, the second of two temporally close events is more likely to contribute to recharge than a similar isolated event of the same magnitude that occurs after a dry period, particularly if the events 5 occur within $24 \mathrm{~h}$ of each other. These findings are consistent with those described by Tan et al. (2007c) for the same environment; they demonstrated that clustered precipitation events tend to lead to more recharge than isolated events. Keeping the modeling results in mind and looking back to the field observations, the fast wetting front movement recorded in the field on DOY 145 (see Fig. 4b) is likely to be a result of higher 10 antecedent moisture content when compared to events of similar volume on DOY 132 and 183.

The weather patterns and subsurface properties in this environment require that daily rather than monthly time scales be used to describe the relationship between precipitation and recharge. Since the moisture drains quickly in this environment, tim15 ing of precipitation (time lapse between events) is a significant factor in determining recharge. This temporal dynamic is not included when precipitation is aggregated by month. Seasonal variations in climate and water table conditions are also critical to describing subsurface moisture fluxes and groundwater recharge. Antecedent moisture content in the shallow vadose zone is dependent on water table depth in addition to timing of previous events; isolated events that occur when the water table is closer to the ground surface will percolate quickly through the shallow subsurface, contributing to groundwater recharge. With the seasonal change in shallow soil moisture that comes with water table fluctuations, the relationship between precipitation patterns and recharge also changes. This is consistent with previous observations by Jones and Banner (2003), and provides a possible mechanism explaining why they observed greater recharge when a higher percent of rainfall occurred during the wet season compared to more evenly distributed precipitation events.

\section{HESSD}

8, 8063-8099, 2011

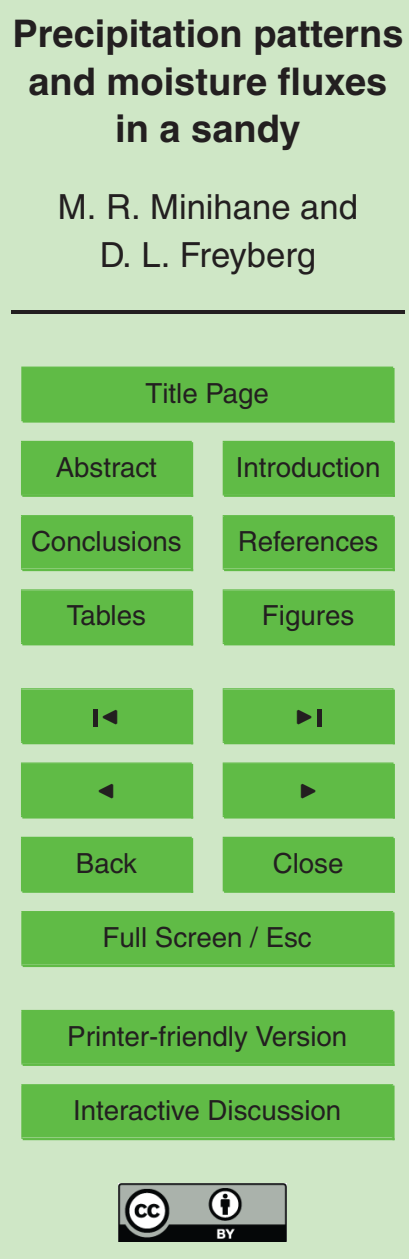




\subsection{Recharge}

While wetting front advancement depends strongly on both antecedent soil moisture conditions and precipitation depth, neither of these factors alone is sufficient to predict the soil moisture response in this environment. The moisture content change below $50.50 \mathrm{~m}$ is strongly correlated to the product of the moisture deficit and the precipitation depth. The high coefficient of determination (Fig. 7) demonstrates that the combination of these terms is a strong predictor of soil moisture response in the top $0.50 \mathrm{~m}$ of soil. This indicates that much of the variability in response to different precipitation events can be attributed to the product of these two factors. In other words, most of the recharge in this environment comes from events with greater precipitation depths that occur when there is a low moisture deficit.

Specifically, for our field site, this means that a higher percent of a precipitation event will contribute to recharge when the total depth is more than $3 \mathrm{~mm}$ per event and the water table is shallower (i.e., during the wet season) or when that event closely follows

15 a preceding event. It follows that more frequent and/or deeper events that occur during the monsoon season contribute more recharge on average than events that occur during the drier season. Therefore, in sandy locations with tropical climate and a shallow water table, water resources planners interested in recharge or soil moisture conditions need to consider identifying threshold precipitation volumes, along with multiple time scales that capture variability in event antecedent conditions and storm frequency. Our results also suggest that recharge in these locations will be sensitive to subtle changes in precipitation patterns such as might be induced by a changing climate.

Acknowledgements. The authors are grateful for project funding from the Singapore Clean Water Program. The authors would like to thank Lloyd Chua, Mzila Ngonidzashe, and Yee

25 Woon Kang for extensive field and logistical support without which the data collection would not have been possible.

\section{HESSD}

8, 8063-8099, 2011

\section{Precipitation patterns and moisture fluxes in a sandy \\ M. R. Minihane and D. L. Freyberg}

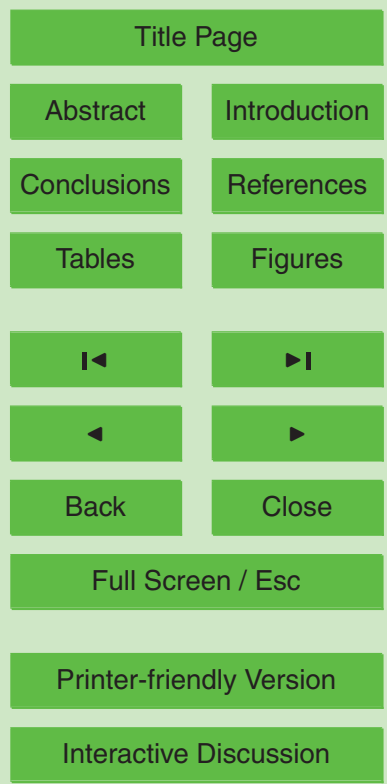




\section{References}

Allen, R. G., Pereira, L. S., Raes, D., and Smith, M.: Crop evapotranspiration: Guidelines for computing crop water requirements, FAO Irrigation and Drainage Paper No. 56, 1998.

Allen, R. G., Walter, I. A., Elliot, R. L., Howell, T. A., Itenfisu, D., Jensen, M. E., Snyder, R. L.

5 (Editors): ASCE's Standardized Reference Evapotranspiration Equation, American Society of Civil Engineers, Reston, VA, USA, 2005.

Bartolino, J. R. and Niswonger, R. G.: Numerical simulation of vertical ground-water flux of the Rio Grande from ground-water temperature profiles, Central New Mexico, U.S. Geological Survey Water-Resources Investigations Report 99-4212, 34 pp., 1999.

Broadbridge, P. and White, I.: Constant rate rainfall infiltration - A versatile nonlinear model, 1. Analytic solution, Water Resour. Res., 24(1), 145-154, 1988.

Campbell Scientific Instruction Manual: TDR probes CS605, CS610, CS630, CS635, CS640, CS645, available at: http://www.campbellsci.com/documents/manuals/tdr-probes.pdf, 2009.

Castillo, V. M., Gómez-Plaza, A., and Martínez-Mena, M.: The role of antecedent soil water content in the runoff response of semiarid catchments: a simulation approach, J. Hydrol., 284, 114-130, 2003.

Choa, V.: Changi East Reclamation Project, in: H. Yoshikuni and K. O. (Editors), Compression and Compaction of Clayey Soils, Taylor \& Francis, Inc., Rotterdam, the Netherlands, 10051017, 1995.

Chua, L. H. C., Lloyd, H., Lo, M., Edmond, Y., Freyberg, D. L., Shuy, E. B., Lim, T. T., Tan, S. K., and Ngonidzashe, M.: Hydrostatigraphy and geochemistry at a coastal sandfill in Singapore, Hydrol. J., 15, 1591-1604, 2007.

California Irrigation Management Information System, www.cimis.water.ca.gov, last access: July 2011.

Davidson, J. M., Stoner, L. R., Nielsen, D. R., and Larue, M. E.: Field measurement and use of soil water properties, Water Resour. Res., 5(6), 1312-1321, 1969.

Fook, F. S.: Some aspects of the hydrometeorology of Singapore, in: The Singapore Story: Physical Adjustments in a Changing Landscape, edited by: Gupta, A. and Pitts, J., Singapore University Press, Singapore, 215-240, 1992.

30 Freeze, R. A.: The mechanism of natural ground-water recharge and discharge 1. Onedimensional, vertical, unsaturated flow above a recharging or discharging ground-water flow system, Water Resour. Res., 5(1), 153-171, 1969.

\section{HESSD}

8, 8063-8099, 2011

\section{Precipitation patterns and moisture fluxes in a sandy}

M. R. Minihane and D. L. Freyberg

\section{Title Page}

\section{Abstract}

Introduction

Conclusions

References

Tables

Figures

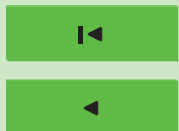

$\rightarrow I$

Back

Close

\section{Full Screen / Esc}

Printer-friendly Version

Interactive Discussion 
Gupta, A. and Pitts, J. (Editors): The Singapore Story: Physical Adjustments in a Changing Landscape, Singapore University Press, Singapore, 423 pp., 1992.

Hillel, D.: Applications of Soil Physics, Academic Press, New York, NY, USA, 385 pp., 1980.

Jones, I. C. and Banner, J. L.: Estimating recharge thresholds in tropical karst island aquifers: Barbados, Puerto Rico and Guam, J. Hydrol., 278(1-4), 131-143, 2003.

Keese, K. E., Scanlon, B. R., and Reedy, R. C.: Assessing controls on diffuse groundwater recharge using unsaturated flow modeling, Water Resour. Res., 41, W06010, doi:10.1029/2004WR003841, 2005.

Lewis, M. F. and Walker, G. R.: Assessing the potential for significant and episodic recharge in southwestern Australia using rainfall data, Hydrol. J., 10(1), 229-237, 2002.

Minihane, M. R.: Shallow subsurface flow paths, tropical hydrology, and groundwater protection, Ph.D. thesis, Stanford University, Stanford, CA, USA, 2008.

Ngonidzashe, M.: Feasibility of utilizing reclaimed land at Changi as a groundwater source, Ph.D. thesis, Nanyang Technological University, Singapore, 2004.

15 Ngonidzashe, M., Ban, S. E., Hwa, T. J. and Koe, L.: Effect of boundary conditions in estimating hydraulic conductivity $(\mathrm{K})$ of a shallow coastal reclaimed land aquifer using the tidal damping method, in: Advances in Hydro-Science and -Engineering, Volume VI: Proceedings of Abstracts and Papers (on CD-ROM) of the 6th International Conference on Hydro-Science and -Engineering, Brisbane, Australia, May 31-June 3, 2004, available at: ftp://ftp.hamburg.baw.de/pub/Kfki/Bib/2004_ICHE_6th/ICHE04_CDROM_pdfs/Mini_ Symposia/04_MS_IV/046_Ngonidzashe-etal.pdf, 2004.

Nolan, B. T., Healy, R. W., Taber, P. E., Perkins, K., Hitt, K. J., and Wolock, D. M.: Factors influencing ground-water recharge in the eastern United States, J. Hydrol., 332(1-2), 187205, 2007.

Singapore National Environment Agency Weather Wise Singapore, available at: http://app2. nea.gov.sg/data/cmsresource/20090721544571208250.pdf, 2010.

Singh, V. P.: Kinematic Wave Modeling, in: Water Resources: Environmental Hydrology, John Wiley \& Sons, Inc., New York, USA, 1424 pp., 1997.

Sisson, J. B., Ferguson, A. H., and van Genuchten, M. T.: Simple method for predicting drainage from field plots, Soil Sci. Soc. Am. J., 44, 1147-1152, 1980.

Smith, R. E.: Approximate soil water movement by kinematic characteristics, Soil Sci. Soc. Am. J., 47, 3-8, 1983.

Smith, R. E.: Infiltration Theory for Hydrologic Applications, Water Resources Monograph, 15,

HESSD

8, 8063-8099, 2011

\section{Precipitation patterns and moisture fluxes in a sandy}

M. R. Minihane and D. L. Freyberg

Title Page

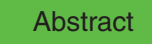

Introduction

Conclusions

References

Tables

Figures

14

4

Back

Full Screen / Esc

Printer-friendly Version

Interactive Discussion 
American Geophysical Union, Washington DC, USA, 212 pp., 2002.

Sophocleous, M. and Perry, C. A.: Experimental studies in natural groundwater-recharge dynamics - the analysis of observed recharge events, J. Hydrol., 81(3-4), 297-332, 1985.

Tan, S. B. K., Shuy, E. B., and Chua, L. H. C.: Effects of meteorological and hydrogeologi5 cal factors on gross recharge percentage at unconfined sandy aquifers with an equatorial climate, Hydrol. Process., 21, 2493-2503, 2007a.

Tan, S. B. K., Shuy, E. B., and Chua, L. H. C: Regression method for estimating rainfall recharge at unconfined sandy aquifers with an equitorial climate, Hydrol. Process., 21, 3514-3526, 2007b.

10 Tan, S. B. K., Shuy, E. B., Chua, L. H. C., and Yee, W. K.: Studies on groundwater recharge characteristics at a reclaimed land site with an equitorial climate using time-series and spectral analysis, Hydrol. Process., 21, 939-948, 2007c.

Tan, S. K., Chua, L. H. C., Ngonidzashe, M., Tay, J. H., and Koe, L. C. C.: Measurements of hydraulic conductivity in a sandfill, in: Advances in Hydro-Science and -Engineering, Volume VI: Proceedings of Abstracts and Papers (on CD-ROM) of the 6th International Conference on Hydro-Science and -Engineering, Brisbane, Australia, May 31-June 3, 2004, available at: ftp://ftp.hamburg.baw.de/pub/Kfki/Bib/2004_ICHE_6th/ICHE04_CDROM_pdfs/Tech_ Contributions/07_TC_VII/077_Tan-etal.pdf, 2004.

Taylor, R. G. and Howard, K. W. F.: Groundwater recharge in the Victoria Nile basin of east Africa: support for the soil moisture balance approach using stable isotope tracers and flow modelling, J. Hydrol., 180, 31-53, 1996.

van Genuchten, M. T.: A closed-form equation for predicting the hydraulic conductivity of unsaturated soils, Soil Sci. Soc. Am. J., 44, 892-898, 1980.

\section{HESSD}

8, 8063-8099, 2011

\section{Precipitation patterns and moisture fluxes in a sandy}

M. R. Minihane and D. L. Freyberg

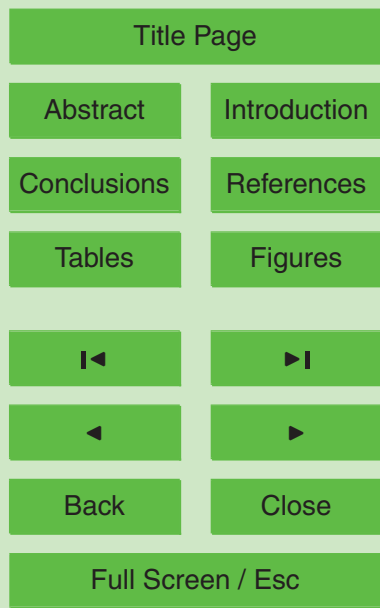

Printer-friendly Version

Interactive Discussion 


\section{HESSD}

8, 8063-8099, 2011

\section{Precipitation patterns} and moisture fluxes in a sandy

Table 1. Summary of model parameters.

\begin{tabular}{ll}
\hline Parameter & Values \\
\hline Saturated hydraulic conductivity $\left(K_{\mathrm{s}}\right)$ & $80 \mathrm{~m} \mathrm{~d}^{-1}, 8 \mathrm{~m} \mathrm{~d}^{-1}$, or $0.8 \mathrm{~m} \mathrm{~d}^{-1}$ \\
Porosity (field saturated moisture content) & 0.36 \\
Residual moisture content & 0.05 \\
van Genuchten $n$ & 2 \\
van Genuchten $\alpha$ & $6 \mathrm{~m}^{-1}$ \\
van Genuchten $\lambda$ & 0.5 \\
Water table depth & $1 \mathrm{~m}, 2 \mathrm{~m}$, or $3 \mathrm{~m}$ \\
\hline
\end{tabular}

M. R. Minihane and

D. L. Freyberg

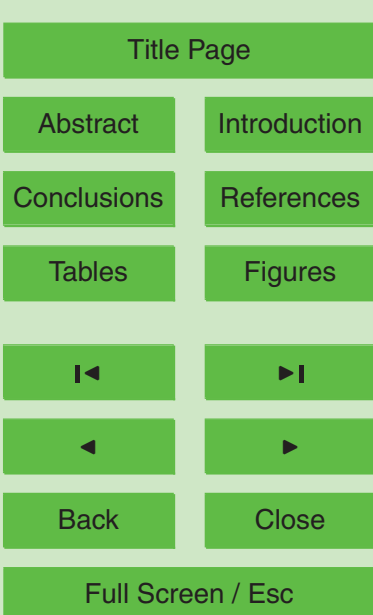

Printer-friendly Version

Interactive Discussion 


\section{HESSD}

8, 8063-8099, 2011

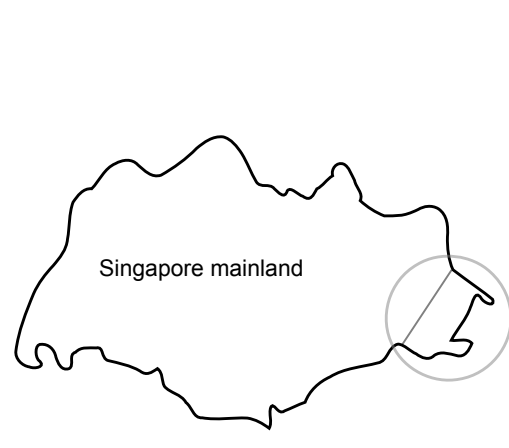

N个

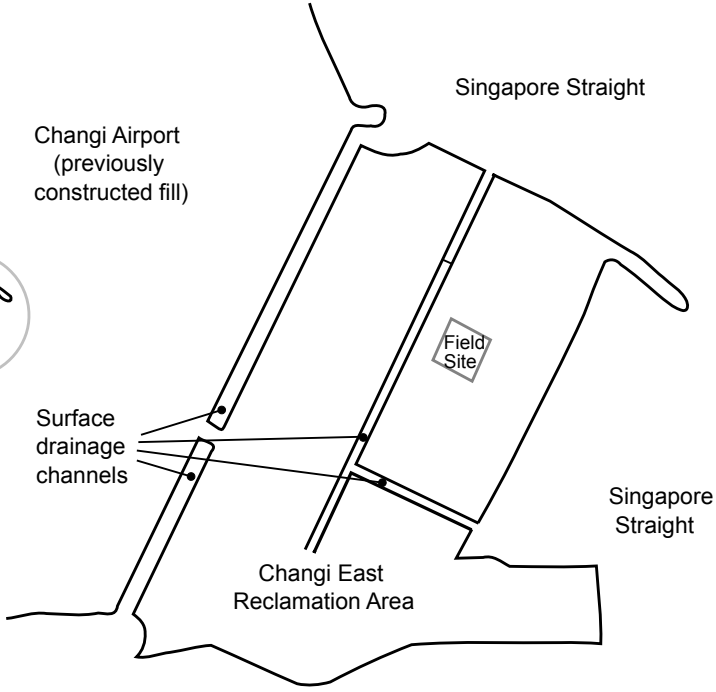

0

Singapore Straight

$3 \mathrm{~km}$

Fig. 1. Field site: Sketch of the Changi East Reclamation Area showing the approximate location of the field site. The sketch at the right is modified from L.H.C. Chua (personal communication, 2003).

\section{Precipitation patterns and moisture fluxes in a sandy \\ M. R. Minihane and D. L. Freyberg \\ Title Page \\ Abstract \\ Introduction \\ Conclusions \\ References \\ Tables \\ Figures \\ 14 \\ -I \\ 4 \\ Back \\ Close}

Full Screen / Esc

Printer-friendly Version

Interactive Discussion 


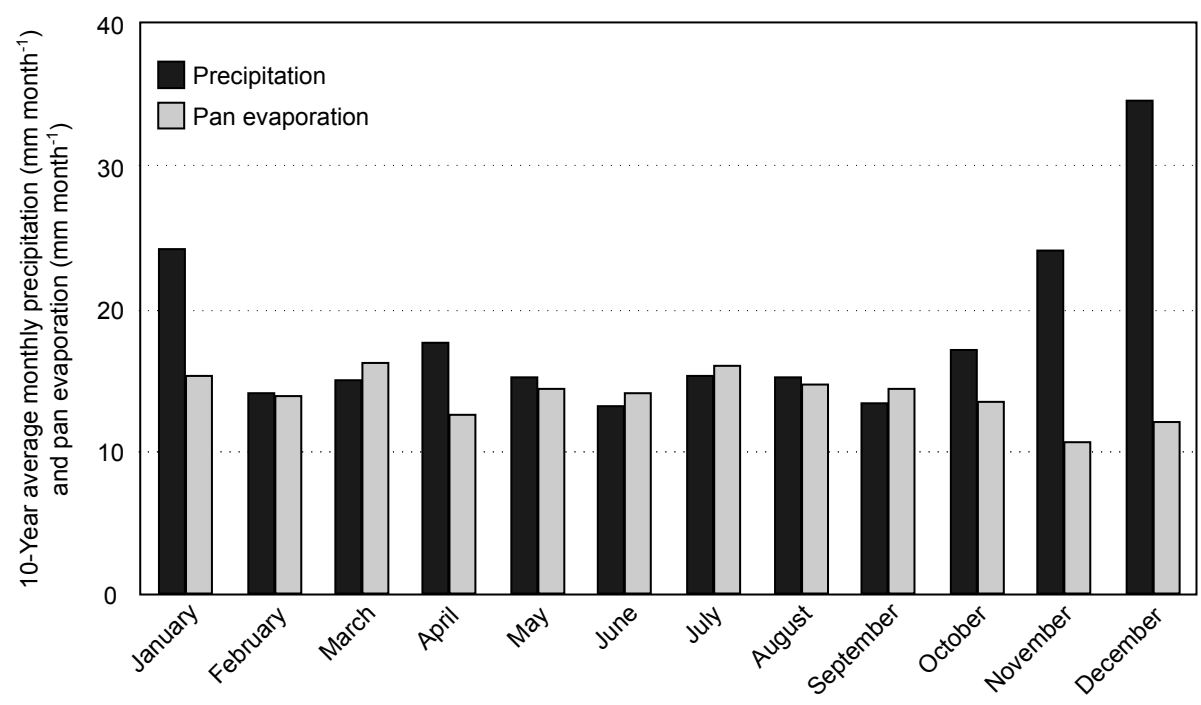

Fig. 2. Hydrometeorology summary: Daily mean precipitation and pan evaporation at the Changi International Airport, 1994-2003. Raw data purchased from the Singapore National Environment Agency in 2004.

\section{HESSD}

8, 8063-8099, 2011

Precipitation patterns and moisture fluxes in a sandy

M. R. Minihane and

D. L. Freyberg

\section{Title Page}

Abstract

Conclusions

Tables

14

4

Back
Introduction

References

Figures

$\rightarrow$

$\checkmark$

Close

\section{Full Screen / Esc}

Printer-friendly Version

Interactive Discussion 


\section{HESSD}

8, 8063-8099, 2011

\section{Precipitation patterns and moisture fluxes in a sandy \\ M. R. Minihane and \\ D. L. Freyberg}
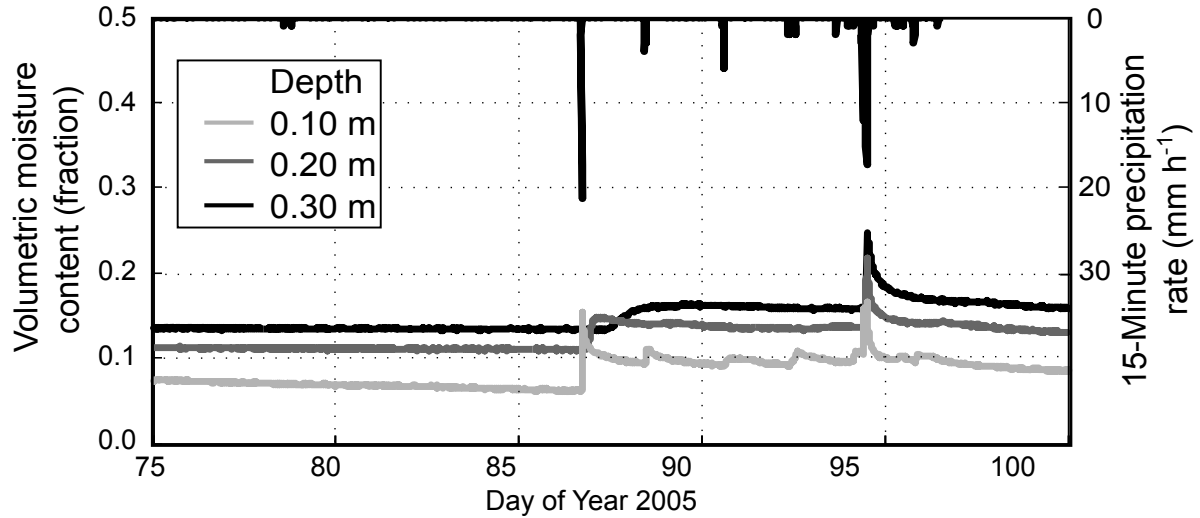

Fig. 3. Field observations of precipitation rate and soil moisture content. Moisture content field data recorded on 10-min intervals from 16 March to 10 April 2005 (DOY 75 to 100). Porosity is 0.36 .

Title Page

Abstract

Introduction

Conclusions

References

Tables

Figures

14

4

Back

Close

Full Screen / Esc

Printer-friendly Version

Interactive Discussion 


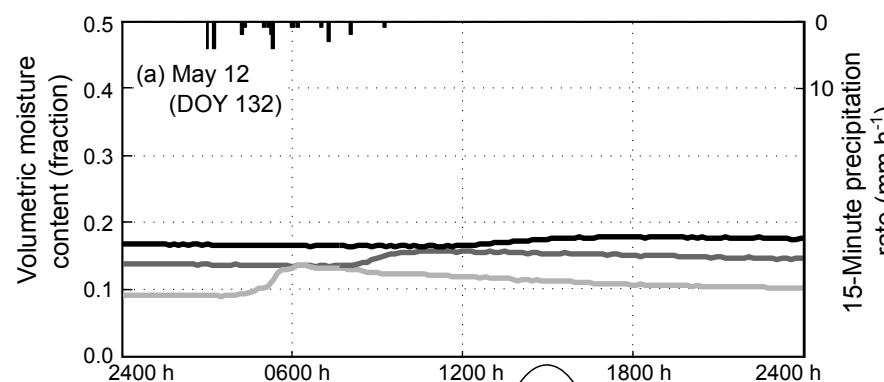

HESSD
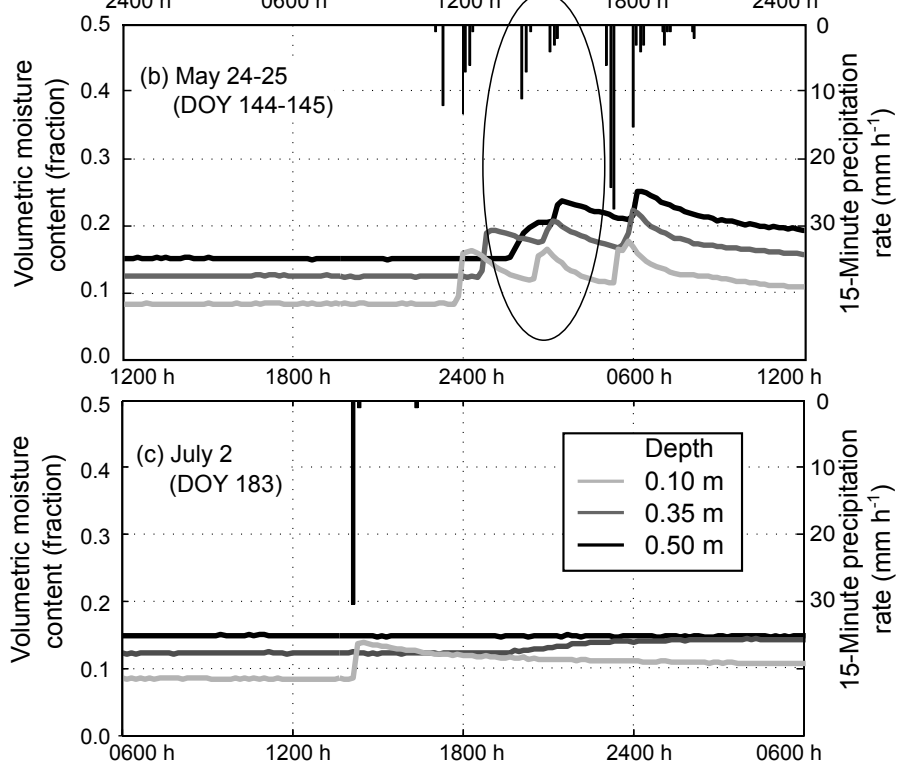

8, 8063-8099, 2011

Precipitation patterns and moisture fluxes in a sandy

M. R. Minihane and D. L. Freyberg

Title Page

Abstract Introduction

Conclusions

References

Tables

Figures

14

$>$ I

4

Back

Close

Full Screen / Esc

Fig. 4. Field observations of 3 precipitation events and soil moisture responses. Moisture content (left axis) and 15-min precipitation (positive downwards, right axis) time series from field observations on (a) 12 May (DOY 132), (b) 24-25 May (DOY 144-145, specific event is circled for clarity), and (c) 2 July (DOY 183), 2005.

Printer-friendly Version

Interactive Discussion

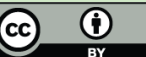




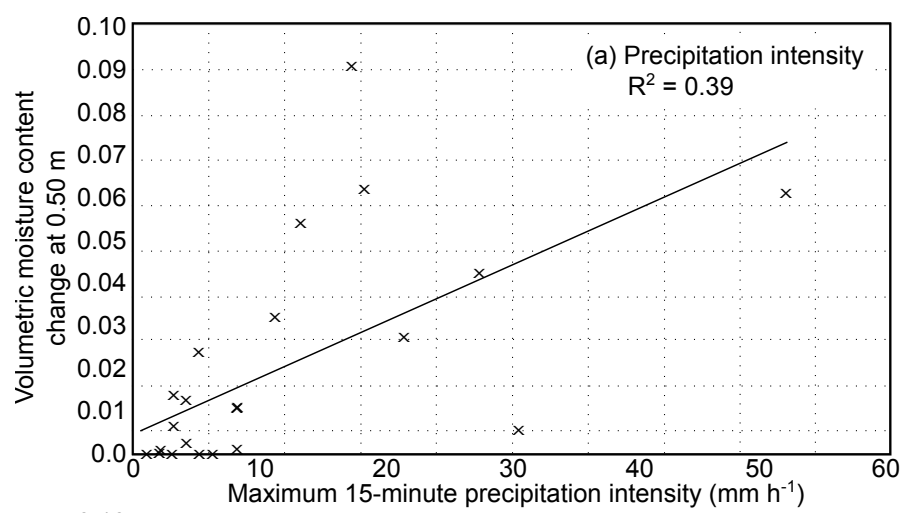

HESSD

8, 8063-8099, 2011

\section{Precipitation patterns} and moisture fluxes in a sandy

M. R. Minihane and

D. L. Freyberg

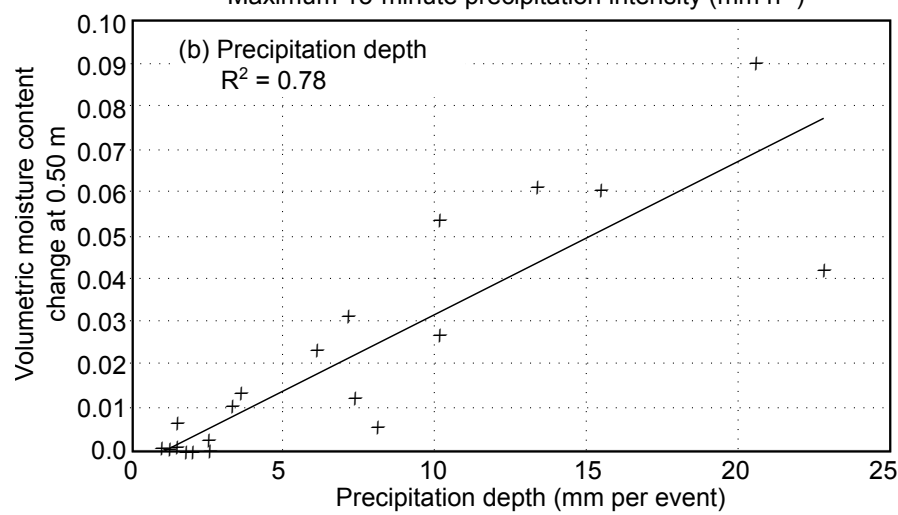

Title Page

Abstract Introduction

Conclusions

References

Tables

Figures

14

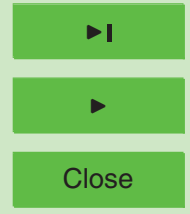

Back

Full Screen / Esc

Fig. 5. Precipitation depth versus intensity. Comparison of the volumetric moisture content change at $0.50 \mathrm{~m}$ versus (a) maximum 15-min precipitation rate and (b) total precipitation depth for each event. Linear trendlines are shown with the corresponding coefficients of determination, $R^{2}$.

Printer-friendly Version

Interactive Discussion 


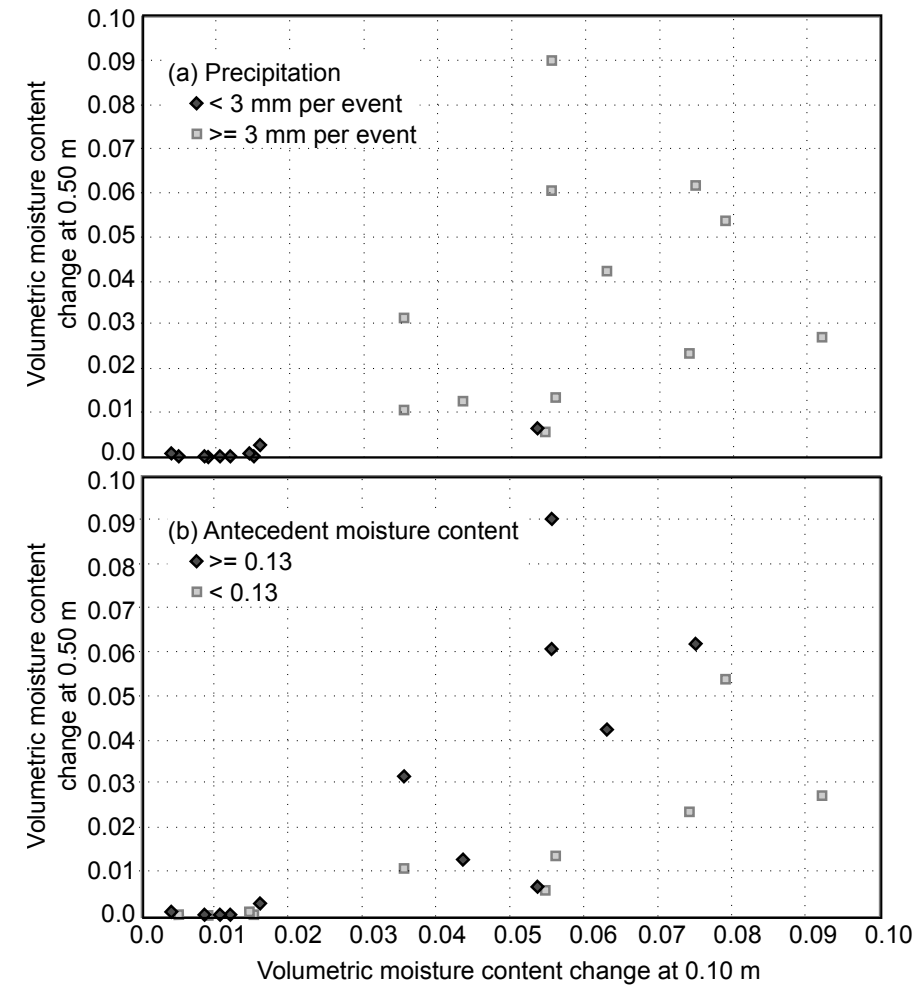

Fig. 6. Moisture content change relative to precipitation depth versus antecedent moisture content. Scatter plots show the moisture content change at $0.50 \mathrm{~m}$ versus $0.10 \mathrm{~m}$ following each precipitation event. (a) The grey squares indicate events with precipitation depths greater than $3 \mathrm{~mm}$ and the black diamonds indicate smaller events. (b) The grey squares indicate events for which the average of observed antecedent moisture content is less than 0.13 and the black diamonds indicate wetter antecedent moisture conditions.

\section{HESSD}

8, 8063-8099, 2011

\section{Precipitation patterns and moisture fluxes in a sandy \\ M. R. Minihane and D. L. Freyberg}

Title Page

\section{Abstract}

Conclusions

\section{Tables}

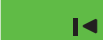

$\triangleleft$

Back

\section{Introduction}

References

Figures

- I

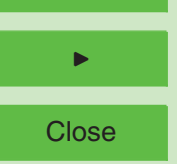

Full Screen / Esc

Printer-friendly Version 


\section{HESSD}

8, 8063-8099, 2011

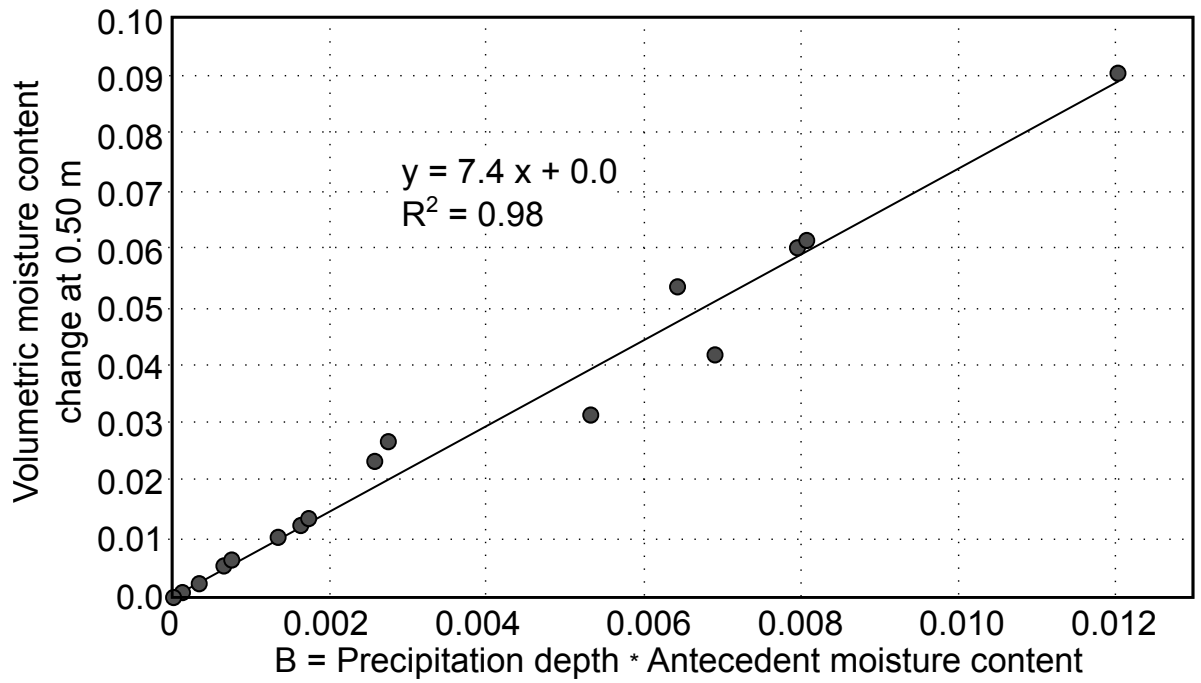

\section{Precipitation patterns and moisture fluxes in a sandy \\ M. R. Minihane and \\ D. L. Freyberg}

\section{Title Page}

\section{Abstract}

Conclusions

Tables

14

$\triangleleft$

Back
Introduction

References

Figures

$\rightarrow$

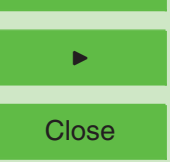

Full Screen / Esc

Printer-friendly Version

Fig. 7. Precipitation depth and antecedent moisture content. Scatter plot of volumetric moisture change at $0.50 \mathrm{~m}$ versus $\mathrm{B}$, the product of precipitation depth and average observed and the corresponding coefficient of determination. 


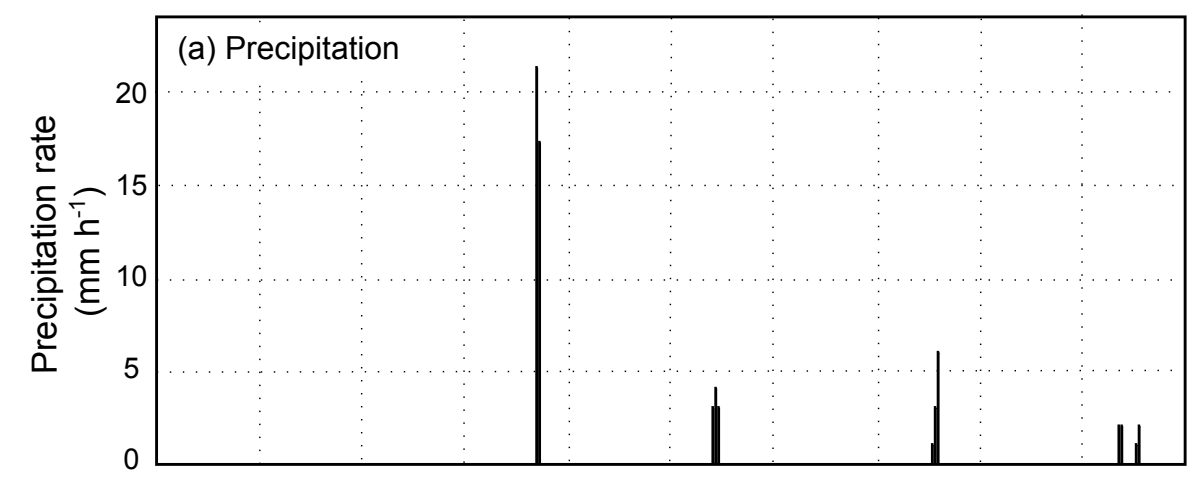

HESSD

\section{8, 8063-8099, 2011}

\section{Precipitation patterns} and moisture fluxes in a sandy

M. R. Minihane and

D. L. Freyberg

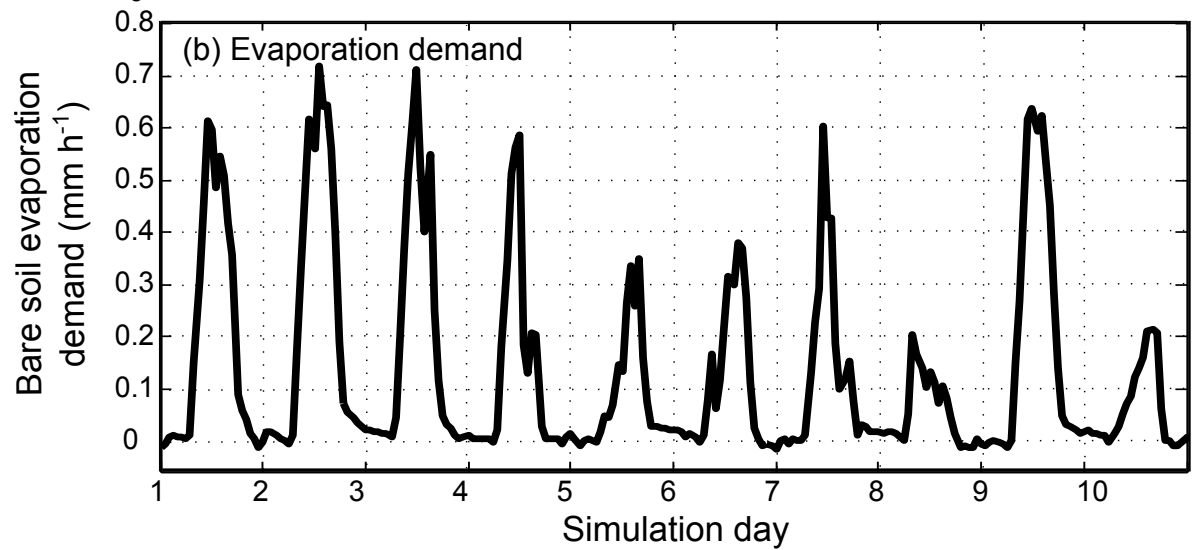

Title Page

Abstract

Conclusions

\section{Tables}

14

4

Back

Full Screen / Esc

Printer-friendly Version

Interactive Discussion 


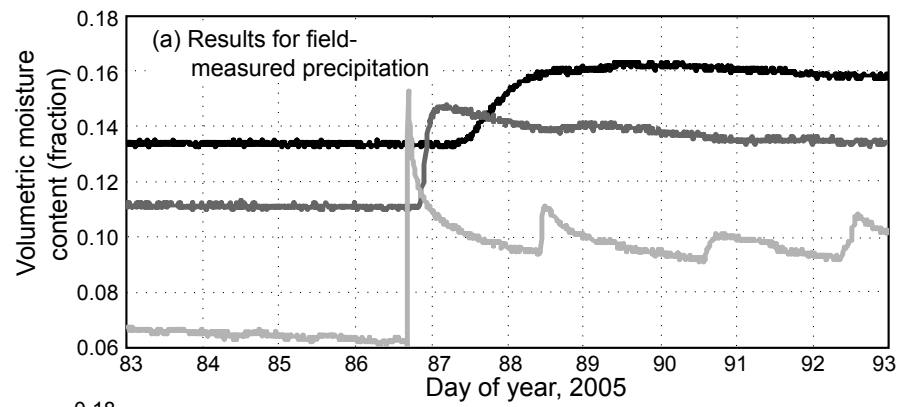

\section{HESSD}

8, 8063-8099, 2011

\section{Precipitation patterns} and moisture fluxes in a sandy

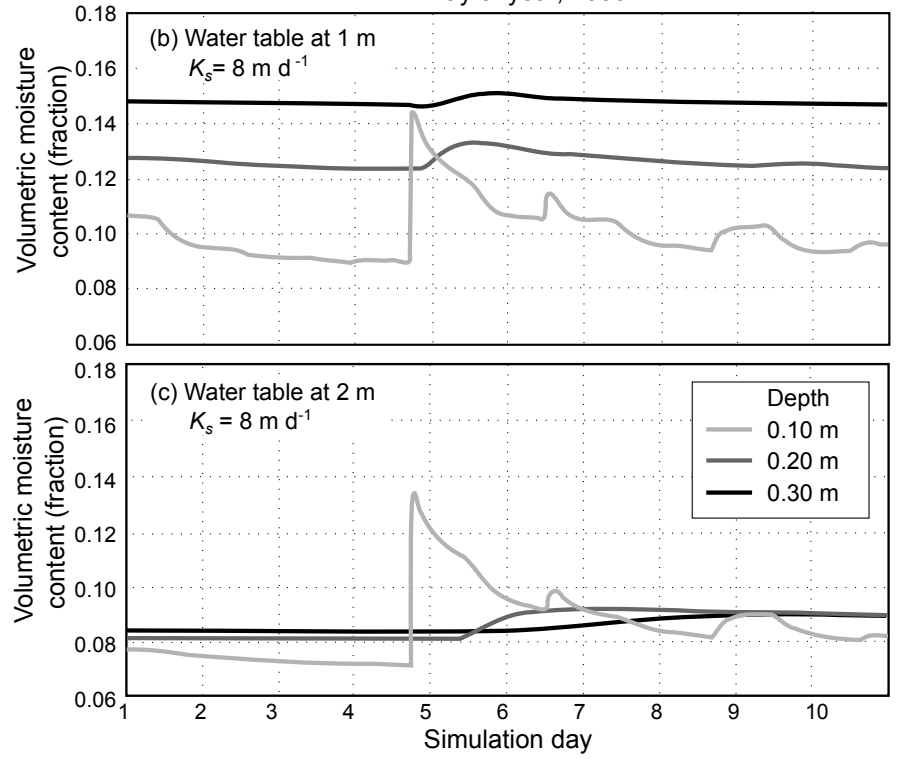

M. R. Minihane and

D. L. Freyberg

\section{Title Page}

\section{Abstract}

Conclusions

\section{Tables}

14

4

Back

Full Screen / Esc

Printer-friendly Version

Interactive Discussion

Fig. 9. Comparison of field observations with modeling results. Moisture content time series for (a) the field measurements and (b-c) the 10-day numerical model with $K_{\mathrm{s}}$ equal to $8 \mathrm{~m} \mathrm{~d}^{-1}$ with the water table at $1 \mathrm{~m}$ and at $2 \mathrm{~m}$. The porosity is 0.36 . 


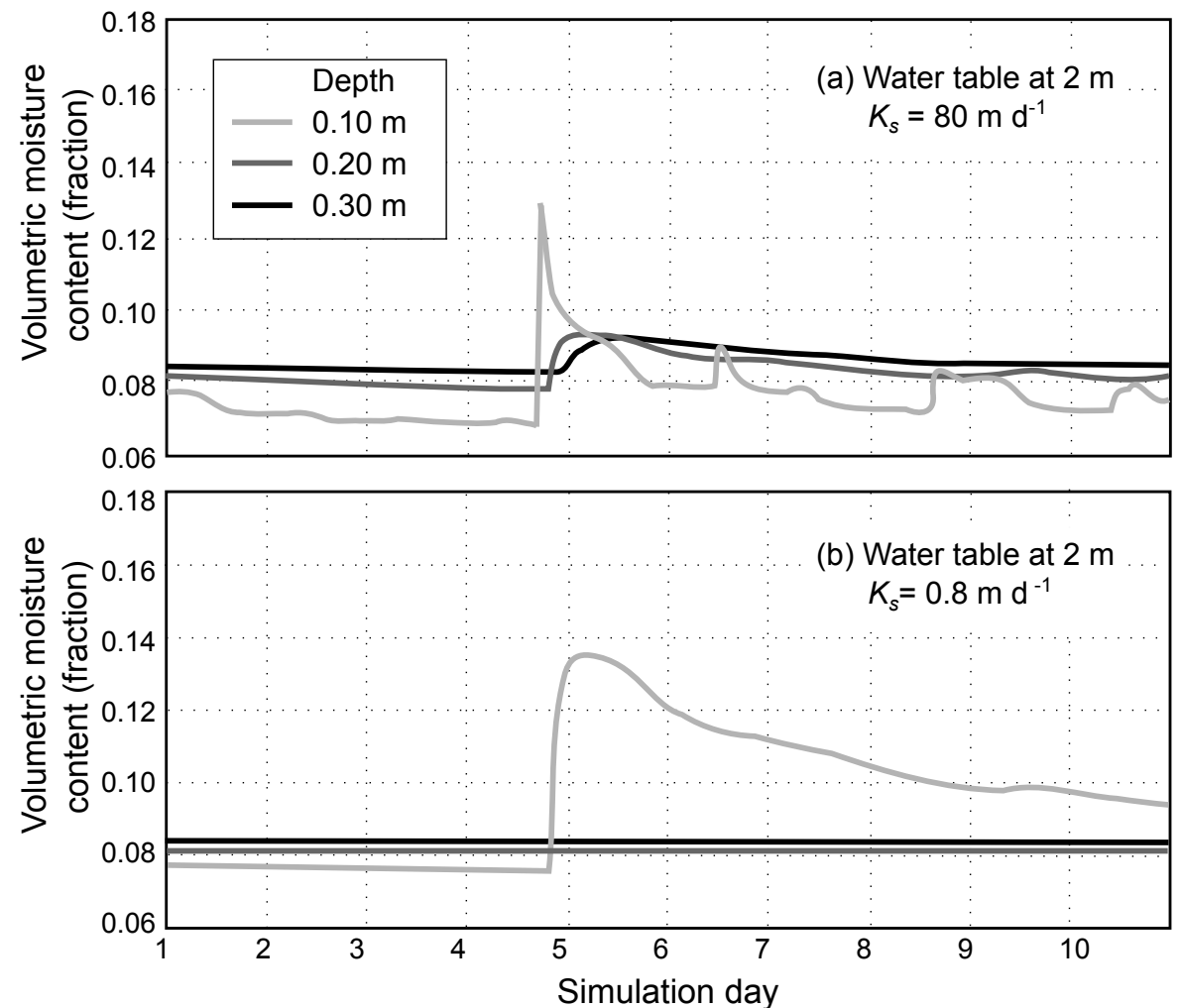

Fig. 10. Effects of saturated hydraulic conductivity on simulated moisture content. Moisture content time series for the 10-day numerical model with the water table at $2 \mathrm{~m}$, and $\mathrm{Ks}$ equal to (a) $80 \mathrm{~m} \mathrm{~d}^{-1}$ and (b) $0.8 \mathrm{~m} \mathrm{~d}^{-1}$. The porosity is 0.36 .

\section{HESSD}

8, 8063-8099, 2011

Precipitation patterns and moisture fluxes in a sandy

M. R. Minihane and

D. L. Freyberg

\section{Title Page}

\section{Abstract}

Introduction

Conclusions

References

Tables

Figures

14

4

Back

Close

Full Screen / Esc

Printer-friendly Version

Interactive Discussion 


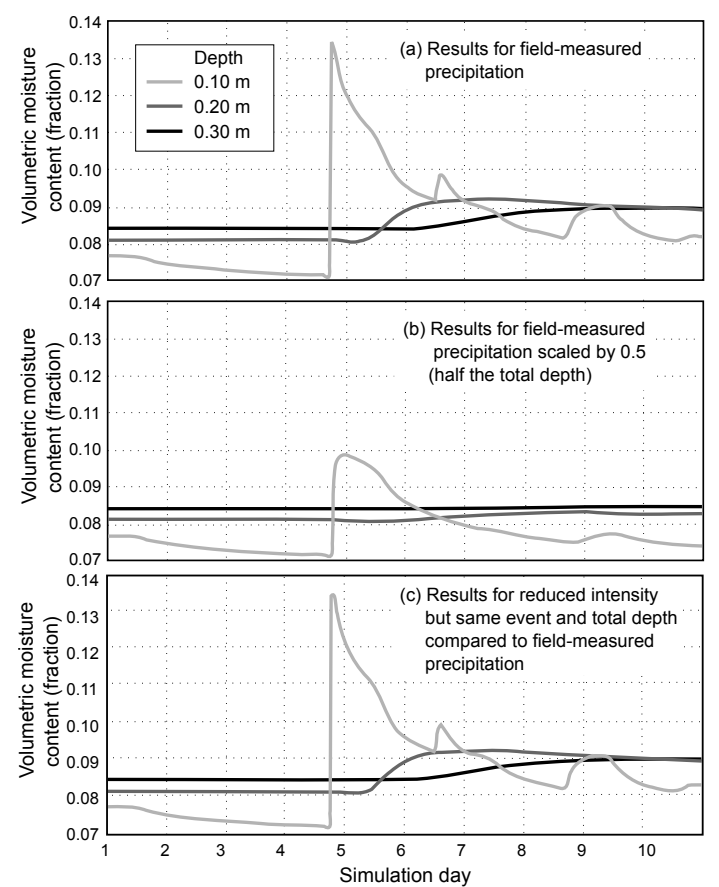

Fig. 11. Effects of precipitation depth and intensity on moisture content. Ten-day simulated moisture content with the water table at $2 \mathrm{~m}$ and $K_{\mathrm{s}}$ equal to $8 \mathrm{md}^{-1}$. (a) Results given fieldmeasured precipitation and evaporation demand shown in Fig. 8 (same data as Fig. 9c, but with a modified vertical scale to match other plots in this figure). (b) Results given the precipitation record shown in Fig. 8 scaled by 0.5. (c) Results given a precipitation record in which each event starts at the same time as in Fig. 8, but is twice as long; the intensity is half the original value but the total precipitation volume is the same. ET demand is the same for all three simulations. Moisture contents at three depths in the domain are shown: $0.10 \mathrm{~m}, 0.35 \mathrm{~m}$, and $0.50 \mathrm{~m}$. Porosity is 0.36 .
HESSD

8, 8063-8099, 2011

\section{Precipitation patterns and moisture fluxes in a sandy}

M. R. Minihane and D. L. Freyberg

\section{Title Page}

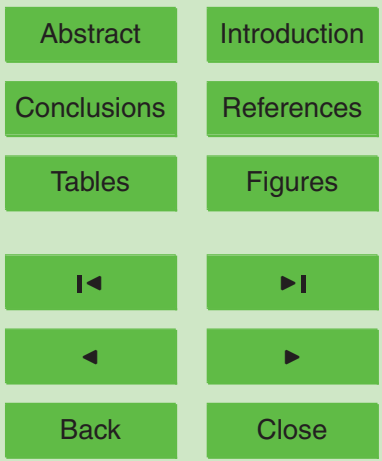

Full Screen / Esc

Printer-friendly Version

Interactive Discussion 


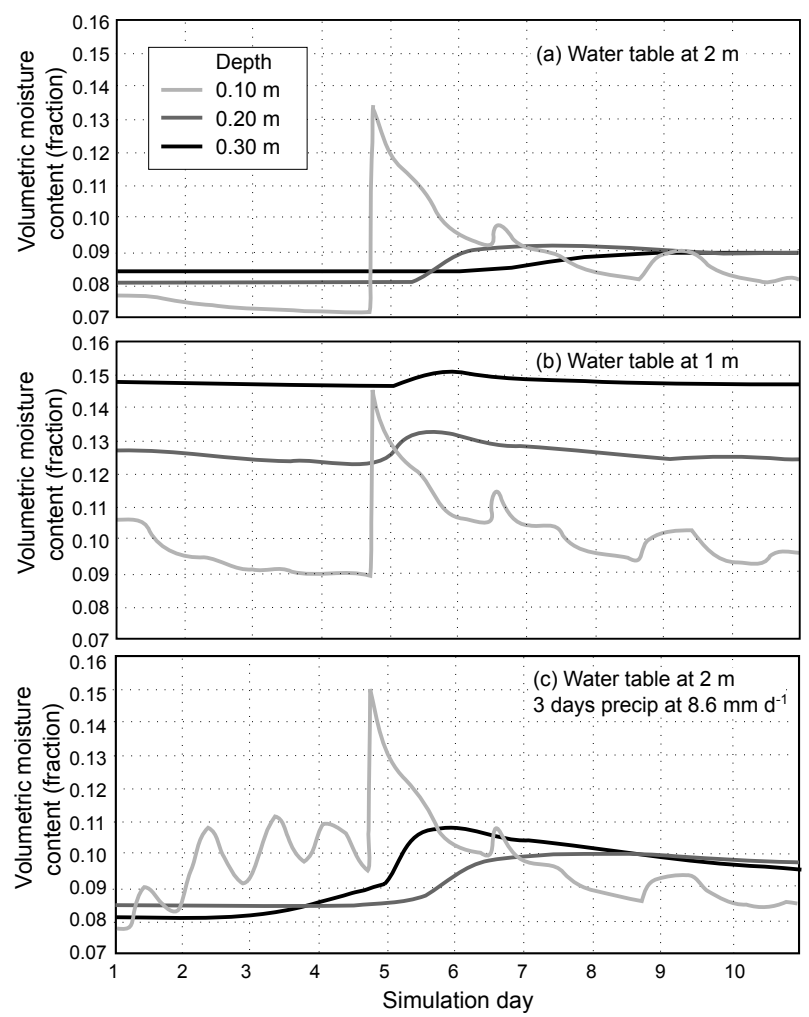

Fig. 12. Effects of antecedent moisture content on soil moisture response to precipitation. Comparison of moisture content time series at three depths for three scenarios to evaluate the impact of antecedent moisture content on the wetting front advancement. Top (a): water table at $2 \mathrm{~m}$ and no precipitation for the first three days. Middle (b): water table at $1 \mathrm{~m}$ and no precipitation for the first three days. Bottom (c): water table at $2 \mathrm{~m}$ and constant precipitation specified $\left(8.6 \mathrm{~mm} \mathrm{~d}^{-1}\right)$ for the first three days.
HESSD

8, 8063-8099, 2011

\section{Precipitation patterns} and moisture fluxes in a sandy

M. R. Minihane and

D. L. Freyberg

\section{Title Page}

\section{Abstract}

Introduction

Conclusions

References

Tables

Figures

14

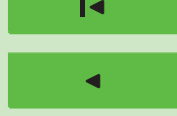

Back

Close

\section{Full Screen / Esc}

Printer-friendly Version

Interactive Discussion 